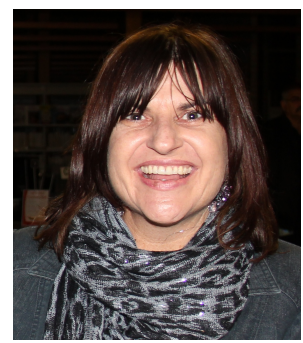

\title{
THE IMPACT OF THE LAW ON CONSULTATION PRACTICES AND PURPOSE: A CASE STUDY OF ABORIGINAL CULTURAL HERITAGE CONSULTATIONS IN NSW
}

\section{Kylie Lingard}

Doctoral student, School of Law, University of New England

Consultation research to date has largely concentrated on how consultation practices generally serve only the purpose of procedural compliance. This article identifies and explores the gap in existing research on the impact of law on consultation practices and purposes. To explore current practices and the potential contribution of law to the nature of consultation practices, the article focuses on the NSW duty to consult Aboriginal people before permitting harm to Aboriginal cultural heritage.

Conventional regulatory approaches to consultation assume that Aboriginal interests are accommodated by the same consultation strategies applied to other stakeholders in rural law and policy. This article uses an administrative law doctrinal research approach to identify the specific issues and requirements for Aboriginal consultation relating to cultural heritage. Consideration is given to the effectiveness of the case study consultation requirements, the duty design, and the recent Land and Environment Court judgment of Ashton Coal Operations Pty Limited v Director-General, Department of Environment, Climate Change and Water. ${ }^{1}$

The article argues that statutory consultation requirements and purposes can, and should, be taken more seriously. The law reform discussion highlighted in the paper considers how identified consultation requirements can be incorporated into Australian Cultural Heritage legislation, and the possible impact of such incorporation on the purpose of the consultation. More broadly, the law reform discussion indicates that when consultation requirements are tailored to suit the purpose of the consultation and the consultation parties, the law can play a positive role in consultation, engagement and capacity building.

\section{Introduction}

Consultation is the seeking of information or advice from others. ${ }^{2}$ It often precedes government decision-making, either as an exercise of discretion or because of a legal requirement to consult. This article considers the duty to consult that arises when a law requires consultation before the making of a government decision.

Consultation research and literature generally argues that institutions implement ineffective consultation practices, ${ }^{3}$ and that consultation fails to fulfil any purpose beyond that of a token

\footnotetext{
Ashton Coal Operations Pty Limited v Director-General, Department of Environment, Climate Change and Water (No 3) [2011] NSWLEC 1249.

2 Oxford Reference Online, The Concise Oxford English Dictionary (2011) <http://www.oxfordreference.com>.

${ }^{3}$ See, eg, Deirdre Wilcock, 'Examining “Inclusiveness" in Adaptive Natural Resource Management' (Paper presented at the Australian Stream Management Conference, New South Wales, 2007); Ian Holland, 'Consultation, Constraints and Norms: the Case of Nuclear Waste' (2002) 61(1) Australian Journal of Public Administration 76; Zeenat Mahjabeen, Krishna Shrestha and John Dee, 'Rethinking Community Participation in Urban Planning: the Role of Disadvantaged Groups in Sydney Metropolitan Strategy' (2009) 15(1) Australasian Journal of Regional Studies 45.
} 
gesture. ${ }^{4}$ Researchers recommend a range of institutional reforms to improve these problems. ${ }^{5}$ The problems are generally identified by studying the relationship between institutions and consultation. ${ }^{6}$ Institutional research has covered topics such as the merit of different consultation practices, ${ }^{7}$ attitudes to consultation, ${ }^{8}$ the benefits of consultation, ${ }^{9}$ and the ability of consultation to influence government decision-making..$^{10}$ There is, however, an absence of research on the relationship between statutory consultation requirements and consultation practices and purposes. ${ }^{11}$ This may be because statutory requirements usually extend no further than requiring a decision-maker to consult before decision-making, ${ }^{12}$ and to take consultation information into account in decision-making. ${ }^{13}$ Despite the predominance of minimal statutory requirements, there is a growing call to research the impact of the law on consultation. ${ }^{14}$ Such research may help improve the problems of ineffective practices and unfulfilled purposes.

\section{Evaluating the duty to consult}

As Chess argues, 'one of the most contentious debates on evaluation concerns which goals to evaluate' ${ }^{15}$ Academics identify the problems with consultation by evaluating consultation against a range of theoretical goals, such as 'empowering citizens' and 'improving agency decisions'. ${ }^{16}$ When it comes to a duty to consult, however, it is possible to distinguish between a theoretical goal and a government objective. As Catt and Murphy suggest:

The connection between particular ... forms of public consultation and the specific ends they are supposed to achieve is one question that needs to be confronted in a more rigorous and systematic fashion. ${ }^{17}$

A duty to consult contains consultation requirements, however minimal. A government may prescribe these requirements for a purpose related to, but distinct from, the objective of the duty to consult. For example, the purpose of the duty to consult may be to persuade people to support a particular option. The purpose of the consultation requirements may be to enable practices that identify and include those most opposed to the option. ${ }^{18}$ Consequently, evaluation of the duty to consult is two-fold: it requires an evaluation of the extent to which consultation

${ }^{4}$ See, eg, Sherry Arnstein, 'A Ladder of Citizen Participation' (1969) 35(4) Journal of the American Planning Association 216, 217; Mahjabeen, Shrestha and Dee, above n 3, 46; Forward NRM, Scoping Study on Indigenous Involvement in Natural Resource Management Decision Making and the Integration of Indigenous Cultural Heritage Considerations into Relevant Murray-Darling Basin Commission Programs, Report to Murray-Darling Basin Commission (2003) 53, 56, 58, 62, 120, 135; Lin, Crase, Brian Dollery and Joe Wallis, 'Conceptualising Community Consultation in Public Policy Formulation: the Case of the Living Murray Debate in the Murray-Darling Basin of Australia' (Working paper, University of New England, 2004) 26.

${ }^{5}$ See, eg, Crase, Dollery and Wallis, above n 4, 7; Holland, above $\mathrm{n} 3$; Wilcock, above $\mathrm{n} 3$.

${ }^{6}$ Lee Godden et al, 'Accommodating Interests in Resource Extraction: Indigenous Peoples, Local Communities and the Role of Law in Economic and Social Sustainability' (2008) 26(1) Journal of Energy \& Natural Resources Law 1, 1; Helena Catt and Michael Murphy, 'What Voice for the People? Categorising Methods of Public Consultation' (2003) 38(3) Australian Journal of Political Science 407, 420.

${ }^{7}$ See, eg, Mahjabeen, Shrestha and Dee, above n 3; D Lloyd, P Van Nimwegen and W E Boyd, 'Letting Indigenous People Talk About Their Country: a Case Study of Cross-Cultural (Mis)Communication in an Environmental Management Planning Process ' (2005) 43(4) Geographical Research 406.

${ }^{8}$ See, eg, Arnstein, above n 4; Wilcock, above n 3; Lloyd, Van Nimwegen and Boyd, above n 7.

${ }^{9}$ See, eg, Crase, Dollery and Wallis, above n 4; Paul Burton, 'Conceptual, Theoretical and Practical Issues in Measuring the Benefits of Public Participation' (2009) 15 Evaluation 263.

${ }^{10} \mathrm{See}$, eg, Lloyd, Van Nimwegen and Boyd, above n 7; Mahjabeen, Shrestha and Dee, above n 3; Holland, above n 3; see generally Godden et al, above n 6, 1; Catt and Murphy, above n 6, 420.

${ }^{11}$ Godden et al, above n 6, 1; Catt and Murphy, above n 6, 420.

${ }^{12}$ See, eg, Environmental Protection and Biodiversity Conservation Act 1999 (Cth) s 131AA(1)(b).

${ }^{13}$ Ibid s 131AA(6).

${ }^{14}$ See Godden et al, above n 6, 1-2; see also Catt and Murphy, above n 6, 420.

${ }^{15}$ Caron Chess, 'Evaluating Environmental Public Participation: Methodological Questions' (2000) 43(6) Journal of Environmental Planning and Management 769, 774; see also Caron Chess and Kristen Purcell, 'Public Participation and the Environment: Do We Know What Works?' (1999) 33(16) Environmental Science \& Technology 2685, 2690.

${ }^{16}$ Chess, ibid; see, eg, John Kane and Patrick Bishop, 'Consultation and Contest: The Danger of Mixing Modes' (2002) 61(1) Australian Journal of Public Administration 87, 88; David Adams and Michael Hess, 'Community in Public Policy: Fad or Foundation?' (2001) 60(2) Australian Journal of Public Administration 13, 17-19; Crase, Dollery and Wallis, above n 4 , 3-5.

${ }^{17}$ Catt and Murphy, above n 6, 408 (emphasis added); see also Catt and Murphy, above n 6, 420; Holland, above n 3, 77.

${ }^{18}$ See generally Kane and Bishop, above n 16, 88. 
requirements enable practices that fulfil the purpose of those requirements; and an evaluation of the extent to which the duty to consult fulfils its intended purpose.

In light of the above discussion, this article considers the following arguments:

1. That statutory consultation requirements lack the standards and specifications necessary to ensure the implementation of effective practices

2. That statutory duties to consult are ill-designed to fulfil the purpose of the consultation

3. That specific law reform measures may improve the problems of ineffective practices and unfulfilled purposes

The article is not a critique of Aboriginal rights or Aboriginal cultural heritage management. It aims is to ignite discussion on the impact of the law on consultation practices and purposes by testing the arguments against the NSW National Parks and Wildlife Act ('NPWA') duty to consult Aboriginal people before permitting harm to Aboriginal cultural heritage. ${ }^{19}$

Evaluation of this duty is appropriate because it is the most recent example of a statutory duty to consult. It is also timely because there are no academic evaluations to inform the impending reform of Aboriginal cultural heritage legislation in NSW. ${ }^{20}$

\section{Contribution to international rural law and policy}

Aboriginal cultural heritage $(\mathrm{ACH})$ protection and management is central to the international goals of Aboriginal rights recognition, sustainable development and Natural Resource Management (NRM). Aboriginal people are increasingly engaged in $\mathrm{ACH}$ protection and management through consultation. This article offers a unique approach to investigating the role of law in consultation, engagement and capacity building in NRM. It interrogates the assumption that key issues relate to good or bad procedures and practices and argues that statutory consultation requirements and purposes can, and should, be taken more seriously and implemented with greater rigour, fairness and due process. The conventional planning and regulatory approach to consultation assumes that Aboriginal interests are accommodated by the same consultation processes that are applied to other stakeholders in rural law and policy. This article identifies very specific issues and requirements for Aboriginal consultation relating to cultural heritage. The research also contributes to the jurisprudence and interdisciplinary approaches for Next Generation NRM Governance being developed by the Australian Centre for Agriculture and Law at the University of New England.

\section{Methodology}

This article applies an administrative law doctrinal research approach to explore the relationship between statutory consultation requirements and consultation practices and purposes. The methodology uses a case study to test arguments related to the practices and purposes of the duty to consult. The arguments and best practice principals are derived from the board spectrum of views, perceptions and experiences found in academic theory, case studies, government reports, $\mathrm{ACH}$ law reform documents and submissions, media articles, and Parliamentary debates.

Issues with the current regime and key requirements for effective consultation were drawn from the views of Aboriginal people and other key stakeholders expressed in stakeholder interviews, submissions to past and current $\mathrm{ACH}$ law reform discussions and government policy documents. The comparative study of $\mathrm{ACH}$ legislation in other jurisdictions was assisted by reports and discussion papers published by the relevant government. The law reform discussion was particularly informed by past and current law reform papers from across Australia, submissions made to recent law reform inquiries, and stakeholder interviews.

\footnotetext{
${ }^{19}$ National Parks and Wildlife Act 1974 (NSW) s 90N ('NPWA'); National Parks and Wildlife Regulation 2009 (NSW) reg $80 C$ (1) ('NPWR').

${ }^{20}$ See generally Working Party for the Reform of Aboriginal Heritage Legislation, 'Reform of NSW Aboriginal Heritage Legislation' (Issues paper draft, NSW Government, 21 March 2011); see, eg, National Native Title Tribunal,

'Commonwealth, state and territory heritage regimes: summary of provisions for Aboriginal consultation', (Report, New South Wales Aboriginal Land Council, December 2010) 76.
} 


\section{Interview participants}

To obtain a balanced view of current consultations, it was appropriate to interview an equal number of representatives from each stakeholder group. Formal interviews were conducted with two Aboriginal stakeholders, two Office of Environment and Heritage employees, and two developer stakeholders. These interviews were conducted in person, or through a questionnaire. Concerns about confidentiality led a further three respondents to request informal participation. These interviews were conducted by telephone. Due to contention surrounding the case study consultations, all nine interview participants requested confidentiality. As such, participants are referenced throughout this article as follows:

- $\quad$ Registered Aboriginal native title claimant representative AP1

- Local Aboriginal Land Council representative AP2

- Local Aboriginal Land Council representative AP3

- Developer DP1

- Developer DP2

- Developer DP3

- Office of Environment and Heritage employee GP1

- Office of Environment and Heritage employee GP2

- Office of Environment and Heritage employee GP3

\section{Case study legal framework}

$\mathrm{ACH}$ includes objects, places and features of significance to Aboriginal people. ${ }^{21} \mathrm{ACH}$ management is a state responsibility. ${ }^{22}$ In NSW, ACH management falls under the National Parks NPWA. ${ }^{23}$ The Office of Environment and Heritage ('OEH') administer the NPWA, and the associated NPWR. ${ }^{24}$

An objective of the NPWA is the conservation of 'places, objects and features of significance to Aboriginal people'. ${ }^{25}$ This object is given partial effect through the strict liability offence of causing harm to an Aboriginal object, or Aboriginal place declared to be of special significance to Aboriginal people. ${ }^{26} \mathrm{~A}$ defence to this offence is that the harm was authorised by an Aboriginal Heritage Impact Permit issued by the Chief Executive of the $\mathrm{OEH}$, or delegate thereof. ${ }^{27}$

Consultation with Aboriginal people before issuing an Aboriginal Heritage Impact Permit used to be just a matter of policy. ${ }^{28}$ In October 2010, consultation became a matter of law when the NSW Government amended the NPWR to include the following requirements:

1. That the developer consult with Aboriginal people, in accordance with the NPWR consultation requirements, before applying for an Aboriginal Heritage Impact Permit ${ }^{29}$

2. That an Aboriginal Heritage Impact Permit application be accompanied by a Cultural Heritage Assessment Report ${ }^{30}$

\footnotetext{
${ }^{21}$ See, eg, NPWA s 2A(1)(b)(i); Environmental Protection and Biodiversity Conservation Act 1999 (Cth) s 528; Office of Environment and Heritage, Guide to Aboriginal Heritage Impact Permit Processes and Decision-Making (August 2011) 2 ('Guide to AHIP Processes and Decision-Making'); Department of Environment, Climate Change and Water NSW, Aboriginal Cultural Heritage Consultation Requirements for Proponents (April 2010) 3 ('ACH consultation requirements for proponents').

22 See generally Heritage Division, Department of Sustainability, Environment, Water, Population and Communities, Introduction to the Aboriginal and Torres Strait Islander Heritage Protection Act (2010) 3.

${ }^{23}$ See NPWA s $2 A(1)(\mathrm{b})(\mathrm{i})$, pt 6.

${ }^{24}$ See generally Office of Environment and Heritage, Aboriginal Culture and Heritage: Legislative Reform (October 2011) <http://www.environment.nsw.gov.au/>.

${ }^{25}$ NPWA s $2 A(1)(\mathrm{b})(\mathrm{i})$.

${ }^{26}$ Ibid s 86.

${ }^{27}$ Ibid ss 87(1), 21(2), 90C(1); see generally Guide to AHIP processes and decision-making, above $\mathrm{n} 21,1$.

${ }^{28}$ See generally Ashton Coal Operations Pty Limited v Director-General, Department of Environment, Climate Change and Water (No 3) [2011] NSWLEC 1249, [52] (Commissioner Pearson and Sullivan AC) ('Ashton'); Department of Environment and Conservation, Interim Community Consultation Requirements for Applicants (2004) ('Interim Community Consultation Requirements for Applicants'); National Native Title Tribunal, above n $20,74$.

${ }^{29}$ NPWR reg $80 \mathrm{C}(1)$; see also NPWA s $90 \mathrm{~N}$.

${ }^{30} \mathrm{NPWR}$ reg $80 \mathrm{D}(1)$.
} 
The duty to consult is based on recognition of Aboriginal responsibilities to $\mathrm{ACH},{ }^{31}$ and recognition of Aboriginal people as experts on $\mathrm{ACH} .{ }^{32} \mathrm{OEH}$ guidelines state that the purpose of the duty is to ensure Aboriginal information informs Aboriginal Heritage Impact Permit decisionmaking. ${ }^{33} \mathrm{OEH}$ guidelines suggest that the purpose of the consultation requirements is to ensure that authoritative and relevant Aboriginal information informs the Cultural Heritage Assessment Report. $^{34}$

\section{Consultation requirements and issues}

The following discussion considers the first argument: that statutory consultation requirements lack the standards and specifications necessary to ensure the implementation of effective practices. Consultation requirements determine the consultation practices that the consulter must implement. Effective practices are those that fulfil an intended purpose. ${ }^{35} \mathrm{OEH}$ guidelines suggest the purpose of the NPWR consultation requirements is to ensure that authoritative and relevant Aboriginal information informs the Cultural Heritage Assessment Report. ${ }^{36}$ Therefore, there will be support for the first argument if the consultation requirements lack the standards and specifications necessary for authoritative and relevant Aboriginal information to inform the Cultural Heritage Assessment Report.

\section{Notification and registration}

Before applying for an Aboriginal Heritage Impact Permit ('AHIP'), the developer must consult with Aboriginal people in accordance with the NPWR consultation requirements. ${ }^{37}$ The developer must invite any registered native titleholder for the plan area to participate in consultation. ${ }^{38}$ If there is no native titleholder, the developer must invite any Aboriginal person who may hold cultural knowledge about Aboriginal objects or declared Aboriginal places in the area. ${ }^{39}$ The developer must obtain these names from organisations such as the Local Aboriginal Land Council, ${ }^{40}$ and from people self-nominating in response to a notice in the local newspaper. ${ }^{41}$

The invitation must state that the purpose of the consultation is to assist the developer in preparing an AHIP application, and to assist the $\mathrm{OEH}$ in considering the application. ${ }^{42}$ Any person claiming to have cultural knowledge of the area has 14 days to register to participate in the consultation. ${ }^{43}$ Once registered, the developer must consult with each registered Aboriginal party ('RAP'). ${ }^{44}$

Interviews with stakeholders and submissions to NSW ACH law reform inquiries identified three major issues with the current notification and registration requirements: failure to require a clear statement of purpose; failure to require only authoritative information; and failure to provide for conflicts of information.

\footnotetext{
${ }^{31}$ ACH Consultation Requirements for Proponents, above n 21, 2.

32 Ibid.

33 Ibid 1.

${ }^{34}$ See ACH Consultation Requirements for Proponents, above n 21, iii, 7-8; see also NSW Government and Department of Environment, Climate Change and Water, National Parks and Wildlife Amendment Bill 2010 (Omnibus Bill) and Regulations: Better Regulation Statement (2011) 1-2 ('Better Regulation Statement'); Department of Environment and Climate Change, Operational Policy: Protecting Aboriginal Cultural Heritage (February 2009 ) 7 ('Operational policy').

${ }^{35}$ Oxford Reference Online, above $\mathrm{n} 2$.

${ }^{36}$ See ACH Consultation Requirements for Proponents, above n 21, iii, 7-8; Better Regulation Statement, above n 34, 1-2; Operational policy, above $\mathrm{n} 34,7$.

${ }^{37}$ NPWR reg $80 C(1)$.

38 Ibid reg $80 \mathrm{C}(3)$.

39 Ibid reg $80 \mathrm{C}(2)$.

$40 \mathrm{lbid}$ reg $80 \mathrm{C}(2)(\mathrm{a})$.

${ }^{41} \mathrm{lbid}$ reg $80 \mathrm{C}(2)(\mathrm{c})$.

42 Ibid reg $80 C(4)(d)$.

${ }^{43}$ Ibid reg $80 \mathrm{C}(4)(\mathrm{e})$.

${ }^{44}$ Ibid regs $80 C(5)(c),(6)-(8)$.
} 
It is well accepted that people share information in accordance with what they understand the purpose of the consultation to be..$^{45}$ If people have different understandings of the purpose, the intended purpose is difficult to achieve. ${ }^{46}$ To ensure achievement of the intended purpose, all parties must be clear on the intended purpose at the outset. ${ }^{47}$

Governments across Australia publicly recognise Aboriginal people as the primary source of information on 'the value of their heritage and how this is best protected and conserved'. ${ }^{48}$ This view is reflected in OEH guidelines that state that the purpose of the NPWR duty to consult is for Aboriginal information to inform AHIP decision-making. ${ }^{49}$ The NPWR notification requirements, however, require the developer to state that the purpose of the consultation is to assist the developer in preparing an AHIP application, and to assist the OEH in considering that application..$^{50}$ While the difference in wording may appear trivial, the consequences of the difference suggest otherwise. It is not a stretch to argue that information exchanged with 'assistants' is different to that exchanged with 'experts'. It is also not a stretch to argue that the subordination of 'experts' in ACH protection to 'assistants' in applications to harm may generate feelings of resentment and mistrust. ${ }^{51}$ As a result, the purpose as stated in the notification requirements may have a negative effect on the information parties share, and the information used to inform the Cultural Heritage Assessment Report.

In regard to the failure to require authoritative information, several issues arise. The first of these goes to representation. Australian governments accept that 'Aboriginal people with traditional responsibilities for heritage are best placed to advise on the manner of protecting their traditional areas and objects'. ${ }^{52}$ It is sometimes difficult to identify who holds primary traditional responsibilities over an area. ${ }^{53}$ What is clear is that native titleholders and registered native title claimants have both proved, to varying degrees, traditional responsibilities over an area. ${ }^{54}$ This supports a claim that native titleholders and registered claimants are 'best placed to advise' on ACH protection.

The NPWR registration requirements do prioritise information from native titleholders. ${ }^{55}$ However, the requirements fail to prioritise registered native title claimants. ${ }^{56}$ Instead, when there is no native titleholder, the requirements allow any person claiming to have cultural

\footnotetext{
${ }^{45}$ See generally Kane and Bishop, above n 16, 89; Meg McLoughlin and Melissa Sinclair, 'Wild Rivers, Conservation and Indigenous Rights: an Impossible Balance?' (2009) 7(13) Indigenous Law Bulletin 3, 3; Catt and Murphy, above n 6, 420; Amanda Gregory, 'Problematizing Participation: a Critical Review of Approaches to Participation in Evaluation Theory' (2000) 6(2) Evaluation 179, 180.

${ }^{46}$ Kane and Bishop, above n 16, 89.

${ }^{47}$ Ibid.

${ }^{48} \mathrm{ACH}$ consultation requirements for proponents, above n 21, 2: see, eg, Operational Policy, above n 34; Department of Sustainability, Environment, Water, Population and Communities, Managing National Heritage Places (18 August 2008) <http://www.environment.gov.au>; Queensland Government, Aboriginal Cultural Heritage Act 2003: Summary (10 August 2011) <http:/ / www.derm.qld.gov.au>; Australian Heritage Commission, Ask First: a Guide to Respecting Indigenous Heritage Places and Values (2002) 6.

${ }^{49} \mathrm{ACH}$ Consultation Requirements for Proponents, above n 21, 7-8.

${ }^{50} \mathrm{NPWR}$ reg $80 \mathrm{C}(4)(\mathrm{d})$.

${ }^{51}$ See generally Mahjabeen, Shrestha and Dee, above n 3, 58; Wilcock, above n 3.

${ }^{52}$ ACH Consultation Requirements for Proponents, above n 21, 8; Department of Environment, Water, Heritage and the Arts (Cth), Indigenous Heritage Law Reform, Discussion Paper (2009) 17 ('Indigenous Heritage Law Reform Discussion Paper'); Interview with GP2 (Questionnaire, 21 August 2011); see Senate Joint Committee on Native Title and the Aboriginal and Torres Strait Islander Land Fund, Parliament of Australia, Eleventh Report of the Parliamentary Joint Committee on Native Title and the Aboriginal and Torres Strait Islander Land Fund: The Aboriginal and Torres Strait Islander Heritage Protection Act 1984 (1998) [7.41].

${ }^{53}$ See generally David Edelman, 'Broader Native Title Settlements and the Meaning of the Term "Traditional Owners"', (Paper presented at AIATSIS Native Title Conference, Melbourne, 9 June 2009) 4-7; Peter Sutton, 'Kinds of Rights in Country: Recognising Customary Rights as Incidents of Native Title' (Occasional Paper Series, National Native Title Tribunal, 2001) 9.

${ }^{54}$ See National Native Title Tribunal, Native Title Claimant Applications; a Guide to Understanding the Requirements of the Registration Test (2008) 16; see, eg, Native Title Act 1993 (Cth) ss 29-30A.

${ }^{55}$ NPWR regs $80 C$ (2), (3)(a)-(b); see generally NSW Aboriginal Land Council, Submission to NSW Department of Environment and Climate Change, Draft Community Consultation Requirements, July 2009, 12.

${ }^{56}$ Interview with AP1 (In-Person Interview, 18 August 2011); Interview with AP2 (Telephone Conversation, 28 June 2011); see generally National Native Title Tribunal, New South Wales and the Australian Capital Territory (31 December 2010) <http://www.nntt.gov.au>.
} 
knowledge of the area to register and provide information on $\mathrm{ACH} .{ }^{57}$ This ensures that information provided by Aboriginal people with proven traditional responsibilities over the area is equal to that provided by any other. ${ }^{58}$ This leads developers and Aboriginal people to agree:

[The NPWR registration requirements] result in 'out of country' Aboriginal involvement in the consultation process. This in turn marginalises and compromises the contribution of 'in country' stakeholders and can even result in non-Aboriginal involvement in the consultation process. ${ }^{59}$

Another potential impediment to the collection of authoritative information is the regulatory failure to end the pre-2010 connection between consultation and employment. The registration requirements allow people to register for consultation as a way of getting site work at up to $\$ 500.00$ per day. ${ }^{60}$ Several interview participants considered that information provided by an RAP hoping for employment may be dictated by what is most likely to secure that employment. ${ }^{61}$ This may result in unauthoritative Aboriginal information informing the Cultural Heritage Assessment Report.

The NSW Aboriginal Land Council notes that the open registration requirements may result in ' $a$ large number of groups registering for one project, making it impossible to find a clear consensus on the significance of an object or place'. ${ }^{62}$ This is particularly concerning in light of the fact that that the NPWR offers no guidance on how to resolve conflicts of information. ${ }^{63}$ Although $\mathrm{OEH}$ guidelines task Aboriginal people with resolving disputes over who speaks for country, ${ }^{64}$ this role may be difficult to fulfil in the face of regulations that require the developer to register every party claiming to have cultural knowledge. ${ }^{65}$ The above issues suggest that the NPWR notification and registration requirements lack the standards and specifications necessary to ensure that authoritative Aboriginal information informs the Cultural Heritage Assessment Report. $^{66}$

\section{Information exchange}

The NPWR provides for two information exchanges. ${ }^{67}$ In the first, the developer must give each RAP detailed information about the proposal and a copy of the proposed methodology for the Cultural Heritage Assessment Report, commonly called the 'CHAR'. ${ }^{68}$ RAPs have 28 days to make written or oral submissions on the proposed methodology. ${ }^{69}$ During this time, the developer must seek information from RAPs on whether there are any objects or places of cultural value to Aboriginal people in the area. $^{70}$

\footnotetext{
${ }^{57}$ NPWR regs $80 \mathrm{C}(2)(\mathrm{a})-(\mathrm{c}),(5)(\mathrm{a})-(\mathrm{c})$; Interview with AP1 (In-Person Interview, 18 August 2011$)$; Interview with DP1 (InPerson Interview, 5 August 2011); Interview with AP2 (Telephone Conversation, 28 June 2011).

58 Interview with AP1 (In-person Interview, 18 August 2011); Interview with AP2 (Telephone Conversation, 28 June 2011 ); Interview with AP3 (Telephone Conversation, 25 July 2011); Interview with DP1 (In-Person Interview, 5 August 2011); Interview with DP3 (Telephone Conversation, 23 June 2011).

59 Urban Development Institute of Australia, Submission to NSW Government, National Parks and Wildlife Amendment Bill 2009 and Draft Community Consultation Requirements for Proponents, July 2009, 8; see also Interview with DP1 (InPerson Interview, 5 August 2011); Interview with AP1 (In-person Interview, 18 August 2011).

60 Interview with AP1 (In-person Interview, 18 August 2011); Interview with AP2 (Telephone Conversation, 28 June 2011 ); Interview with DP1 (In-person Interview, 5 August 2011); Interview with DP3 (Telephone Conversation, 23 June 2011 ); but see $\mathrm{ACH}$ Consultation Requirements for Proponents, above n 21, 9.

${ }^{61}$ Interview with AP1 (In-person Interview, 18 August 2011); Interview with AP2 (Telephone Conversation, 28 June 2011 ); Interview with DP1 (In-person interview, 5 August 2011).

${ }^{62}$ NSW Aboriginal Land Council, above n 57, 13.

${ }^{63}$ Urban Development Institute of Australia, above n 59, 8; Interview with DP1 (In-Person Interview, 5 August 2011); NSW Aboriginal Land Council, above n 55, 15; see generally Catt and Murphy, above n 6, 416.

${ }^{64}$ ACH Consultation Requirements for Proponents, above n 21, 15; Interview with GP2 (Questionnaire, 21 August 2011 ).

${ }^{65}$ NPWR reg $80 C(5)$; Interview with AP1 (In-Person interview, 18 August 2011).

${ }^{66}$ Interview with AP1 (In-Person Interview, 18 August 2011); Interview with AP2 (Telephone Conversation, 28 June 2011 ); Interview with AP3 (Telephone Conversation, 25 July 2011); Interview with DP1 (In-Person Interview, 5 August 2011); Interview with DP3 (Telephone Conversation, 23 June 2011).

${ }^{67} \mathrm{NPWR}$ regs $80 \mathrm{C}(5)-(6),(8)$.

${ }^{68}$ Ibid regs $80 \mathrm{C}(5)(\mathrm{c}),(6)(\mathrm{a})$.

${ }^{69}$ Ibid reg $80 \mathrm{C}(6)(\mathrm{b})$.

70 Ibid reg $80 \mathrm{C}(7)$.
} 
The second information exchange requires the developer to give a copy of the draft CHAR to each RAP. ${ }^{71}$ RAPs have 28 days to make written or oral submissions. ${ }^{72}$ The CHAR must include:

- an assessment of the significance of objects or declared places in the plan area

- a description of actual or likely harm to those objects or places

- practical measures to protect and conserve those objects or places

- practical measures to avoid or mitigate harm to those objects or places

- copies of consultation submissions ${ }^{73}$

Interviews with stakeholders and submissions to NSW ACH law reform inquiries identified four major issues with the current information exchange requirements: failure to require appropriate mode; failure to require early engagement; failure to obtain Aboriginal information on the CHAR elements; and failure to require a developer to take consultation submissions into account.

The purpose of the consultation requirements is to ensure that authoritative and relevant Aboriginal information informs the CHAR. ${ }^{74}$ For relevant information to inform the CHAR, the consultation mode must be appropriate and adapted to the consultation parties. ${ }^{75}$ Despite recognition that the written notice and submission mode of consultation may exclude information from Aboriginal people, ${ }^{76}$ the NPWR merely requires developers to provide certain information. This allows developers to send RAPs complex written documents with no explanation or interpretation. ${ }^{77}$ This may affect the capacity of a RAP to give 'a proper expression of opinion or advice' ${ }^{78}$ Furthermore, despite recognition that oral submissions are an important source of $\mathrm{ACH}$ information, ${ }^{79}$ and despite the NPWR allowing a RAP to make an oral submission, ${ }^{80}$ there is no requirement that the developer record, verify or consider information contained in oral submissions. The developer is only required to include copies of consultation submissions in the CHAR. ${ }^{81}$ Interview participants suggest that these submissions are either written by the developer, ${ }^{82}$ or contain a general statement that everything is significant. ${ }^{83}$ These issues suggest that the NPWR mode of consultation may prevent relevant information from informing the CHAR.

Academics and the $\mathrm{OEH}$ agree that consultation advice is most likely to be taken into account if consultation occurs early in the development planning process. ${ }^{84}$ Although the NSW government considers that the consultation requirements ensure 'Aboriginal submissions ... are taken into account' ${ }^{85}$ the consultation requirements make no provision for early engagement. This absence allows $\mathrm{OEH}$ internal decision-making guidelines to state that a decision-maker must have proof of

\footnotetext{
${ }^{71}$ Ibid reg $80 C(8)(a)$.

72 lbid reg $80 \mathrm{C}(8)(\mathrm{b})$

${ }^{73}$ Ibid regs 80D(2)-(3)(a).

${ }^{74}$ See ACH Consultation Requirements for Proponents, above n 21, iii, 7-8; see also Better Regulation Statement, above n 34, 1-2; Operational Policy, above n 34; see generally William Jonas, 'Consultation with Aboriginal People About Aboriginal Heritage' (Report, Australian Heritage Commission, 1991) 1.

${ }^{75}$ See, eg, Council of Australian Governments, Best Practice Regulation: a Guide for Ministerial Councils and National Standard Setting Bodies (October 2007) 31.

${ }^{76}$ NSW Government Better Regulation Office, Consultation Policy (November 2009) 6-7; see, eg, Wilcock, above n 3; Russell Goldflam, 'Noble Salvage: Aboriginal Heritage Protection and the Evatt Review' (1997) 3(88) Aboriginal Law Bulletin 4 <http:/ / www.austlii.edu.au/>; Ashton [2011] NSWLEC 1249, [87]; Jonas, above n 74, 8; McLoughlin and Sinclair, above $\mathrm{n} 45$.

${ }_{77}$ Interview with AP3 (Telephone Conversation, 25 July 2011).

78 Jonas, above n 74, 1, 9; see NSW Government Better Regulation Office, above n 76, 6; Australian Heritage Commission, above n 48, 9-11; see generally Delia Rodrigo and Pedro Andrés Amo, 'Background Document on Public Consultation' (OECD, 2005), 1; Norman Schwartz and Anne Deruyttere, 'Community Consultation, Sustainable Development and the Inter-American Development Bank' (1996), 4; see, eg, Ashton [2011] NSWLEC 1249, [87].

${ }^{79}$ See Ashton [2011] NSWLEC 1249, [81]-[85], [97]; see also Wilcock, above n 3; Goldflam, above n 76.

${ }^{80}$ NPWR regs $80 C(6)(b),(8)(b)$.

${ }^{81}$ Ibid regs $80 \mathrm{D}(2)-(3)(\mathrm{a})$.

82 Interview with DP3 (Telephone Conversation, 23 June 2011).

${ }^{83}$ Interview with AP1 (In-Person Interview, 18 August 2011); Interview with AP2 (Telephone Conversation, 28 June 2011); Interview with AP3 (Telephone Conversation, 25 July 2011); Interview with DP1 (In-Person Interview, 5 August 2011).

${ }^{84} \mathrm{ACH}$ Consultation Requirements for Proponents, above n 21, 3; Sylvia Roughan, 'It's Not Just About Sacred Sites: a Qualitatve Analysis of the Community Consultation Process of the 2009 Review of the Aboriginal Heritage Act 1988' (Report, Rural Solutions SA, 2010) 24, 6-7; Paul Martin, Robyn Bartel, Jack Sinden, Neil Gunningham, Ian Hannam, 'Developing a Good Regulatory Practice Model for Environmental Regulations Impacting on Farmers' (Research report, Australian Farm Institute, July 2007) 28; see generally Chess and Purcell, above n 15, 2691.

${ }^{85}$ Better Regulation Statement, above n 34, 20.
} 
development consent before a issuing an AHIP. ${ }^{86}$ A developer obtains development consent after assessing practical measures to protect and conserve Aboriginal objects or declared places, and practical measures to avoid or minimise harm to those objects or places ${ }^{87}$ An AHIP application is only made if a developer determines harm to an object or declared place is unavoidable. ${ }^{88}$ Consequently, most of the CHAR information is determined before NPWR consultation, usually through consultation conducted as part of the planning process. ${ }^{89}$

Of further concern is that despite recognition of Aboriginal people as experts in $\mathrm{ACH}$ protection and conservation, ${ }^{90}$ the NPWR only requires the developer to seek Aboriginal information on whether there are any objects or places of cultural value to Aboriginal people in the plan area. ${ }^{91}$ There is no requirement to seek Aboriginal information on:

- the significance of Aboriginal objects or declared places

- the actual or likely harm to those objects or places

- practical measures to protect and conserve those objects or places

- practical measures to avoid or mitigate harm to those objects or places

Of most concern is that the requirements make no provision for Aboriginal information on, or assessment of, significance. This is despite widespread recognition that Aboriginal people should determine the significance of $\mathrm{ACH} .{ }^{92} \mathrm{~A}$ significance assessment requires equal consideration of the 'social/cultural, historic, aesthetic and scientific (archaeological) significance' of Aboriginal objects and declared places. ${ }^{93}$ The NPWR only requires the developer to seek information on whether there are Aboriginal objects or places of cultural value in the plan area. ${ }^{94}$ The failure to link Aboriginal people and information to the significance assessment allows $\mathrm{OEH}$ guidelines to task the developer with assessing the significance of Aboriginal objects and declared places. ${ }^{95}$ In reality, developers hire archaeologists to prepare the CHAR. ${ }^{96}$ This raises the concern, repeatedly expressed in judicial dicta and academic literature, that archaeological values will dominate Aboriginal values in the significance assessment of objects and declared places. ${ }^{97}$ The requirements also fail to maintain the connection between objects, places and landscape features. An assessment of objects is inseparable from an assessment of places and landscape features. ${ }^{98}$ Further, information on places and features may clarify the value of Aboriginal

\footnotetext{
${ }^{86}$ Guide to AHIP Processes and Decision-Making, above n 21, 17.

${ }^{87}$ Department of Environment, Climate Change and Water, Due Diligence Code of Practice for the Protection of Aboriginal Objects in New South Wales (Department of Environment, Climate Change and Water, September 2010) 1-2 ('Due Diligence Code of Practice'); Interview with DP1 (In-Person Interview, 5 August 2011); see, eg, City of Sydney, Planning and Building Approvals (30 August $2011<$ http://www.cityofsydney.nsw.gov.au>.

${ }^{88}$ Due Diligence Code of Practice, above n 87, 2; Interview with DP1 (In-Person Interview, 5 August 2011).

${ }^{89}$ Interview with DP2 (Questionnaire, 12 October 2011); see generally Roughan, above n 84, 24-25; see also Australian Heritage Commission, above $\mathrm{n} 48,10$.

${ }^{90}$ ACH Consultation Requirements for Proponents, above n 21, 2: see, eg, Department of Sustainability, Environment, Water, Population and Communities, above n 48; Queensland Government, above n 48; Australian Heritage Commission, above n 48, 6 .

${ }^{91}$ NPWR reg $80 C(7)$.

${ }^{92}$ ACH Consultation Requirements for Proponents, ibid: see, eg, Department of Sustainability, Environment, Water, Population and Communities, above n 48; Queensland Government, above n 48; Australian Heritage Commission, above $\mathrm{n} 48,6$.

${ }^{93}$ ACH Consultation Requirements for Proponents, ibid, 7; Ashton [2011] NSWLEC 1249, [135]; The Burra Charter: The Australia ICOMOS Charter for Places of Cultural Significance 1999 art 1.2 ('Burra Charter').

${ }^{94}$ NPWR reg $80 C(7)$.

${ }^{95}$ See, eg, Ashton [2011] NSWLEC 1249, [135]; ACH Consultation Requirements for Proponents, above n 21, 7; Burra Charter art 1.2.

${ }^{96}$ Interview with DP1 (In-Person Interview, 5 August 2011); Interview with DP2 (Questionnaire, 12 October 2011); David Guilfoyle, 'Aboriginal Cultural Heritage Regional Studies: an Illustrative Approach' (Report, Department of Environment and Conservation NSW, 2006) 6.

97 See Ashton [2011] NSWLEC 1249, [81]-[85], [97], [134]; see generally Guilfoyle, above n 96, 5-6; Annie Clarke and Chris Johnston, 'Time, Meaning, Place and Land: Social Meaning and Heritage Conservation in Australia', (Paper presented at the Scientific Symposium, ICOMOS 14th General Assembly, Zimbabwe, 27-31 October 2003) 2; Aboriginal Cultural Heritage Working Group, 'The Future Management of Aboriginal Cultural Heritage in New South Wales', (Discussion paper, NSW Government, September 1995) 66; Richard Parsons, 'We Are All stakeholders Now: the Influence of Western Discourses of "Community Engagement" in an Australian Aboriginal Community' (2008) 2(2) Critical Perspectives on International Business 99, 101; Denis Byrne, Helen Bradshaw, Tracy Ireland, 'Social Significance' (Discussion paper, NSW National Parks and Wildlife Service, June 2001) 141-142; Marcus Lane and Liana Williams, 'Color Blind: Indigenous Peoples and Regional Environmental Management' (2008) 28 Journal of Planning Education and Research $38,39$.

${ }^{98}$ Clarke and Johnston, ibid, 3.
} 
objects. ${ }^{99}$ While the NPWR requires the developer to seek information on whether there are any objects or places in the plan area, ${ }^{100}$ there is no requirement to seek information on whether there are any landscape features in the plan area. The failure to maintain the connection between objects, places and features may prevent relevant Aboriginal information from informing the cultural heritage assessment of objects and declared places.

Another impediment to authoritative and relevant information is the failure to provide for culturally sensitive information. Culturally sensitive information is often directly relevant to the cultural heritage assessment of objects and declared places. ${ }^{101}$ Traditional lore and custom may require that information on objects or places remains secret or confidential. ${ }^{102}$ This is why OEH guidelines encourage the developer and RAP to agree on protocols for dealing with sensitive or confidential information. ${ }^{103}$ However, the consultation requirements fail to require parties to develop protocols and fail to accommodate secret or confidential information. These regulatory failures may prevent a RAP from sharing relevant information with the developer. ${ }^{104}$

Lastly, if the consultation is to inform decision-making, decision-makers must be 'genuinely prepared to take on board objections and conflicting claims'. ${ }^{105}$ To avoid relying on human sincerity, legislation typically requires the decision-maker to consider consultation information. ${ }^{106}$ The NPWR consultation requirements, however, contain no requirement for the developer to consider consultation information when preparing the CHAR. Further, there is no consultation on the final methodology, or the final CHAR. This means there is no way a RAP can verify that consultation information has been fairly used or used at all.

\section{Preliminary conclusions on consultation requirements}

The purpose of the NPWR consultation requirements is to ensure authoritative and relevant Aboriginal information informs the CHAR. The above evaluation, however, suggests that the consultation requirements lack the standards and specifications necessary for authoritative and relevant Aboriginal information to inform the CHAR. The notification and registration requirements allow for the registration of parties that may not hold authoritative information. The information exchange requirements fail to ensure that relevant Aboriginal information informs the significance assessment, or the assessment of practical alternatives to destruction. As a result, the above evaluation provides support for the argument that statutory consultation requirements lack the standards and specifications necessary to ensure the implementation of effective practices.

\section{The duty to consult}

This section considers the second argument: that statutory duties to consult are ill-designed to fulfil the purpose of the consultation. The purpose of the NPWR duty to consult is to ensure that Aboriginal information informs AHIP decision-making. ${ }^{107}$ The duty aims to inform AHIP decisionmaking through the CHAR. ${ }^{108}$ The preceding evaluation revealed that the consultation requirements lack the prerequisites for authoritative and relevant Aboriginal information to inform the CHAR. Evaluation of the NPWR duty to consult requires evaluating whether compliance with the consultation requirements satisfies the prerequisites for informed decisionmaking.

\footnotetext{
99 Ibid; see also Ashton [2011] NSWLEC 1249, [85], [88], [97].

${ }^{100}$ NPWR reg $80 C(7)(b)$.

${ }^{101}$ See, eg, Australian Heritage Commission, above n 48, 13; Elizabeth Evatt, 'Review of the Aboriginal Heritage and Torres Strait Islander Heritage Protection Act 1984 (Cth)' (Report, Australian Government, 22 August 1996) 47-52.

102 See generally Evatt, above n 101, 47-52.

${ }^{103}$ ACH Consultation Requirements for Proponents, above n 21, 13.

104 Heritage Division, above n 22, 10-11.

${ }^{105}$ Kane and Bishop, above n 16, 88.

${ }^{106}$ See, eg, NPWA s 90K(1)(f).

107 ACH Consultation Requirements for Proponents, above n 21, 1; Office of Environment and Heritage, above $\mathrm{n} 24$; see generally Catt and Murphy, above n 6, 407, 409, 420; Kane and Bishop, above n 16, 88.

${ }^{108}$ See NPWR reg $80 D(1)$
} 
The prerequisites for informed decision-making in this case study are found in the NPWA s 90K(1). An AHIP decision-maker must consider the following matters only:

- significance of objects or declared places in the plan area

- actual or likely harm to those objects or places

- practical measures to protect and conserve those objects or places

- practical measures to avoid or mitigate harm to those objects or places

- documents accompanying the application

- NPWA objectives

- social and economic consequences of the decision

- consultation results, including copies of consultation submissions

- whether the developer substantially complied with the consultation requirements ${ }^{109}$

The NPWR duty to consult includes a stipulation that an AHIP application 'is not invalid merely because the applicant ... failed to comply with any one or more of the requirements' ${ }^{110}$ In light of this, the Land and Environment Court recently stated in Ashton Coal Operations Pty Limited $v$ Director-General, Department of Environment, Climate Change and Water:

In our view ... a finding that there has not been substantial compliance with those requirements would not of itself warrant refusal of an application, but would be a matter to be weighed against the other considerations in $\mathrm{s} 90 \mathrm{~K}(1)$. The significance of such a finding would go to whether the decision-maker had available sufficient material to consider properly each of the other matters specified in s $90 \mathrm{~K}(1)$, in particular those matters going to the significance of the Aboriginal objects and the actual or likely harm to those objects. ${ }^{111}$

This statement suggests three things:

1. That informed decision-making requires sufficient material on each decision-making criterion

2. That substantial compliance with the NPWR consultation requirements provides the decisionmaker with sufficient material to properly consider each decision-making criterion

3. That the duty to consult is adequately designed to inform AHIP decision-making

The Court suggested that the NPWR duty to consult is sufficiently designed to inform decisionmaking because the decision-making criterion focuses on objects. ${ }^{112}$ As such, archaeological information on objects is sufficient to inform decision-making. ${ }^{113}$ The following evaluation tests this view by considering:

1. The reasoning in Ashton

2. Whether compliance with the requirements provides sufficient information to properly consider each decision-making criterion

3. Whether substantial compliance with the requirements is sufficient to inform decisionmaking

\section{The reasoning in Ashton}

The OEH refused to grant Ashton Coal an AHIP because Ashton failed to substantially comply with the consultation requirements. As such, the decision-maker had insufficient information to properly consider each decision-making criterion. ${ }^{114}$ Ashton invoked its statutory right to a merits review of the refusal in the Land and Environment Court. ${ }^{115}$ The challenge became a request for consent orders when Ashton and the OEH agreed on AHIP terms and conditions during the merit hearing. ${ }^{116} \mathrm{~A}$ consent order judgment requires the Court to consider 'whether it is

\footnotetext{
${ }^{109}$ NPWA s $90 \mathrm{~K}(1),(2)$.

${ }^{110}$ NPWR reg $80 C(9)$.

${ }^{111}$ Ashton [2011] NSWLEC 1249, [115].

${ }_{112}$ Ibid [135].

113 Ibid [134].

${ }^{114}$ Ibid [4].

115 Ibid [1]; NPWA s 90L(1)(a).

${ }^{116}$ Ashton [2011] NSWLEC 1249, [5].
} 
lawful and appropriate to make the consent orders'. ${ }^{117}$ The Court consented to the AHIP pending a minor amendment. ${ }^{118}$

The Court found Ashton had not complied with the notification and registration requirements, or the requirement to consult on the proposed methodology and draft CHAR. ${ }^{119}$ The Court noted the dominance of archaeological information on objects in Ashton's CHAR. ${ }^{120}$ The Court considered such a CHAR an 'unbalanced cultural assessment' that failed to meet 'good practice'. ${ }^{121}$ Nevertheless, the Court found that the decision-making criterion focuses on objects. ${ }^{122}$ This led the Court to conclude:

While there were respects in which the consultation process engaged in by Ashton did not comply with the requirements of the legislation, we are satisfied that the results of the consultation, including the submissions made by Aboriginal stakeholders as part of the process relied upon by Ashton in the AHIP application and during the course of these proceedings, have provided sufficient evidence to enable proper consideration of the matters specified in s $90 \mathrm{~K}(1)$. While we have expressed concerns as to whether all aspects of the cultural significance of the Aboriginal objects the subject of the AHIP have been considered, we are satisfied that the archaeological evidence provided ... has been thorough. ${ }^{123}$

The Court only had sufficient information to consider each decision-making criterion after supplementing Aboriginal submissions made during consultation with oral submissions made during the hearing. ${ }^{124}$ This highlights the need for consultation requirements to provide adequately for oral submissions. The implication most relevant to evaluation of the duty to consult is that archaeological information on objects is sufficient to inform AHIP decisionmaking. Further support for this implication is found in the Court's constant reference to archaeologists as expert witnesses, ${ }^{125}$ and the making of consent orders despite insufficient information on 'all aspects of cultural significance'. ${ }^{126}$ The following discussion tests the truth of this implication by exploring the information necessary to consider properly each decisionmaking criterion and whether substantial compliance with the consultation requirements provides the decision-maker with that information.

\section{Does compliance provide sufficient information to properly consider each decision-making criterion?}

Proper consideration of actual or likely harm to Aboriginal objects requires Aboriginal identification of those objects. ${ }^{127}$ Proper consideration of the significance of objects or declared places requires Aboriginal information on the social, cultural, historical and aesthetic value of those objects and places. ${ }^{128}$ Proper consideration of protection, conservation, avoidance and mitigation measures requires Aboriginal information on how the object or place may be 'best protected and conserved'. ${ }^{129}$

Granted, the requirement to seek information on whether there are objects or places of cultural value in the plan area provides for RAP identification of objects and places. ${ }^{130}$ It does not provide

\footnotetext{
117 Ibid.

118 Ibid [134], [137].

119 Ibid [113].

120 Ibid [82]-[97].

${ }^{121}$ Ibid [85], [87]

122 Ibid [88], [135].

123 Ibid [134] (emphasis added).

124 Ibid [134].

${ }^{125} \mathrm{See}, \mathrm{eg}$, ibid [45], [66], [75], [78], [89], [94], 97].

${ }^{126}$ Ibid [134].

${ }^{127}$ See ACH Consultation requirements For Proponents, above n 21, 7 .

128 Ibid; see also Ashton [2011] NSWLEC 1249, [82]-[97].

129 See ACH Consultation Requirements for Proponents, above n 21, 2, 7: see, eg, Operational Policy, above n 34; Department of Sustainability, Environment, Water, Population and Communities, Managing National Heritage Places (18 August 2008) <http://www.environment.gov.au>; Queensland Government, above n 34; Australian Heritage Commission, above $\mathrm{n} 48,6$.

${ }^{130}$ NPWR reg $80 C(7)$.
} 
for the seeking of Aboriginal information on the values that comprise significance, or on how objects or declared places may be best protected and conserved. Furthermore, compliance with the open registration requirements may cause the decision-maker to rely on non-authoritative information. It is therefore unlikely that compliance with the consultation requirements will provide the decision-maker with sufficient Aboriginal information to consider properly the first four decision-making criteria. ${ }^{131}$

Proper consideration of the NPWA objectives requires sufficient Aboriginal information on objects, places and landscape features of significance to Aboriginal people, and places of social value to Aboriginal people. ${ }^{132}$ Compliance with the requirements only provides for RAP identification of objects and places in the plan area. There is no requirement to seek RAP information on:

- landscape features

- the significance of objects, places and features

- the social value of places

Furthermore, a compliant developer is under no obligation to consider consultation information when preparing the CHAR. Therefore, compliance with the requirements does not ensure the decision-maker has sufficient information to consider properly the NPWA objectives. ${ }^{133}$

The requirement to consider the NPWA objectives imports a requirement to consider the principles of ecologically sustainable development ('ESD'), as defined by the Protection of the Environment Administration Act 1991 (NSW). ${ }^{134}$ Proper consideration of ESD so defined requires the decision-maker to balance economic and protection interests. ${ }^{135}$ The NPWR vests control of the consultation and the CHAR in the developer. This control no doubt ensures the decisionmaker has sufficient information to consider economic interests. In light of the fact there is no requirement for the developer to collect Aboriginal information on how $\mathrm{ACH}$ may be best protected and conserved, ${ }^{136}$ compliance is unlikely to provide the decision-maker with sufficient information to balance economic and protection interests.

Proper consideration of ESD so defined also requires enough information for the decision-maker to consider the cumulative impacts to regional cultural values. ${ }^{137}$ The developer must only seek information on whether there are objects or places of cultural value in the area. The developer is not required to seek information on the actual cultural values of those objects or places. Compliance with the requirements therefore does not ensure the decision-maker has sufficient information to consider properly the cumulative impacts to regional cultural values. ${ }^{138}$

Proper consideration of economic and social consequences of the decision requires sufficient information of socio-economic consequences such as job loss, ${ }^{139}$ and socio-cultural consequences such of destruction of 'places of social value to the people of New South Wales'. ${ }^{140}$ The decision-maker must notify the developer of any intent to refuse an AHIP, and consider any submission made by the developer in response. ${ }^{141}$ This ensures the decision-maker has sufficient information to consider the economic consequences of making the decision. However, as there is no requirement to collect Aboriginal information on social values, compliance with the duty does

\footnotetext{
${ }^{131}$ But see Ashton [2011] NSWLEC 1249, [135].

${ }^{132}$ See NPWA ss 2A(1)(b)(i)-(iii); see generally Better Regulation Statement, above n 34, 2; ACH Consultation requirements for Proponents, above $\mathrm{n} 21$, iii.

133 But see Ashton [2011] NSWLEC 1249, [135].

${ }^{134}$ NPWA ss 2A(2), 5; Protection of the Environment Administration Act 1991 (NSW) s 6(2).

135 Protection of the Environment Administration Act 1991 (NSW) s 6(2); see Operational Policy, above n 36.

${ }^{136}$ See generally Christopher Schroeder, 'Public Choice and Environmental Policy: a Review of the Literature' (Scholarship series paper no 175, Duke Law School, 5 January 2009) 2-3, 11.

137 Operational Policy, above n 34, 26; NPWA s 2A(2); Protection of the Environment Administration Act 1991 (NSW) s 6(2)(b); see also Anderson v Director General of the Department of Environmental and Climate Change \& Anor [2008] NSWCA 337, [15] (Spigelman CJ, Tobias JA, Macfarlan JA) ('Anderson v DECC No 2').

${ }^{138}$ See, eg, Ashton [2011] NSWLEC 1249, [135]; Burra Charter art 1.2; ACH Consultation Requirements for Proponents, above $\mathrm{n} 21,7$.

139 See, eg, Ashton [2011] NSWLEC 1249, [117]-[120].

140 See NPWA s 2A(1)(b)(ii).

141 NPWA ss $90 \mathrm{C}(3)(\mathrm{a})-(\mathrm{d})$.
} 
not ensure the decision-maker has sufficient information to consider properly the social consequences of the decision.

Proper consideration of consultation results requires sufficient information on consultation undertaken and consultation submissions received. ${ }^{142}$ Developers and Aboriginal interview participants suggest that it is easy to provide information on how many letters were sent, how many phone calls were made, and how many responses were received. ${ }^{143}$ In regard to consultation submissions, the developer must include copies of submissions in the CHAR. ${ }^{144}$ As there is no requirement to record, verify or consider oral submissions, compliance does not ensure the decision-maker is privy to oral submissions. Interview participants suggest that written submissions typically contain a general statement that everything is significant. ${ }^{145}$ However, written submissions may also reveal 'a divergence of views within the Aboriginal community as to the ... presence of significant objects and sites in the AHIP area'. ${ }^{146}$ The requirements contain no guidance on how to resolve these conflicts of information. Instead, compliance with the registration requirements may exacerbate conflicts of information. In this case, compliance may make proper consideration of consultation results difficult.

\section{Is substantial compliance sufficient to inform decision-making?}

The above evaluation casts doubt on the implication that archaeological information on objects is sufficient to inform decision-making. Proper consideration of the significance of Aboriginal objects and declared places, the NPWA objectives, the principles of ESD and the social consequences of the decision requires Aboriginal information on the social, cultural, aesthetic and historic value of objects, places and landscape features. Proper consideration of protection, conservation, avoidance and mitigation measures requires authoritative Aboriginal information on how an object or declared place may be best protected or conserved. The requirement to seek information on whether there are any places of cultural value in the plan area further suggests that archaeological information on objects is insufficient to inform consideration of each decision-making criterion. ${ }^{147}$ In light of this evaluation, the implication that archaeological information on objects is sufficient to inform decision-making appears outdated. ${ }^{148}$

For the duty to consult to be adequately designed to fulfil its purpose, substantial compliance with the consultation requirements must provide the decision-maker with sufficient material to consider properly each decision-making criterion. The above evaluation indicates that substantial compliance with the consultation requirements fails to provide the decision-maker with sufficient Aboriginal information to consider properly each decision-making criterion. This suggests the NPWR duty to consult is ill-designed to inform decision-making.

\section{Judicial review and consultation}

Statutory provisions surrounding the NPWR duty to consult ensure that defects in duty design are an insufficient basis for impugning an AHIP approval in proceedings for judicial review. ${ }^{149}$ Judicial review concerns the legality of the decision. ${ }^{150}$ This means the Land and Environment Court may only invalidate an AHIP approval if the decision-maker:

- failed to afford procedural fairness

- failed to follow correct procedure

- acted outside decision-making power, in that the decision-maker failed to consider a relevant consideration, acted for an improper purpose, or made a decision that was

\footnotetext{
142 See Ashton [2011] NSWLEC 1249, [102]-[107]; NPWR reg 80D(3)(a).

143 Interview with DP1 (In-Person Interview, 5 August 2011); Interview with DP3 (Telephone Conversation, 23 June 2011 ).

${ }^{144}$ NPWR reg $80 \mathrm{D}(3)$.

145 Interview with AP1 (In-Person Interview, 18 August 2011); Interview with DP3 (Telephone Conversation, 23 June 2011 )

${ }^{146}$ Ashton [2011] NSWLEC 1249, [107].

${ }^{147}$ NPWR reg $80 C(7)(\mathrm{b})$.

148 See generally Guilfoyle, above n 96, 5-6; Clarke and Johnston, above n 97, 2; Byrne, Bradshaw, Ireland, above n 97 , 141-142.

149 NPWA s 90P; Land and Environment Court Act 1979 (NSW) s 20(2)(b).

${ }^{150} \mathrm{See}$, eg, Anderson v DECC No 2 [2008] NSWCA 337, [16].
} 
manifestly unreasonable 151

Prior to October 2010, Aboriginal parties had to establish a right to be consulted based on a special interest in the subject matter. ${ }^{152}$ Even if the Aboriginal party established the right, the Court considered that procedural fairness required nothing more than notice of a proposed decision, and the right to make a submission. ${ }^{153}$ As the decision-maker could approve an AHIP on any terms and conditions the decision-maker thought fit, ${ }^{154}$ challenges based on incorrect procedures, or acting outside power, rarely succeeded. ${ }^{155}$ In the one case, the Court found a decision invalid, ${ }^{156}$ the same decision was simply remade using correct procedure. ${ }^{157}$

Granted, the post-2010 duty to consult establishes a right to be consulted. ${ }^{158}$ However, statutory provisions surrounding the NPWR duty to consult are likely to protect decisions based on insufficient information from attack. Substantiating an $\mathrm{OEH}$ breach of procedural fairness is unlikely because fairness is now a matter of statutory construction, ${ }^{159}$ and the NPWR makes it clear an AHIP application is valid notwithstanding a failure to comply with the consultation requirements. ${ }^{160}$ In any event, the OEH is unlikely to grant an AHIP if the developer fails to give Aboriginal people notice and the opportunity to make a submission at some stage in the development planning process. ${ }^{161}$ Substantiating an argument that the decision-maker followed incorrect procedures is unlikely because all a decision-maker has to do to follow correct procedures is consider consultation results, and consider whether the developer substantially complied with the consultation requirements. A RAP may argue that the consultation was so inadequate it forced the decision-maker to act outside decision-making powers. However, as Dr Chris McGrath observes:

Judicial review is typically of little use for environmental litigation where it is the poor nature of an administrative decision that needs to be redressed. If the Minister or their delegate has 'ticked all the right boxes' and been careful in writing their reasons for a decision ... then what is essentially a very poor decision allowing highly damaging development may not be challenged. ${ }^{162}$

\section{Preliminary conclusions on duty design}

The purpose of the NPWR duty to consult is for Aboriginal information to inform OEH decisionmaking. Fulfilment of this purpose requires the decision-maker to have sufficient Aboriginal information to consider properly each decision-making criterion. The design of the NPWR duty to consult ensures the decision-maker has sufficient information on the archaeological value of objects, and the economic interests at stake. However, even perfect compliance with the consultation requirements fails to provide the decision-maker with sufficient Aboriginal information on each decision-making criterion. This provides support for the argument that statutory duties to consult are ill-designed to fulfil the purpose of the consultation.

\footnotetext{
151 See generally Redfern Legal Centre Publishing, The Law Handbook: Your Practical Guide to the Law in New South Wales (Lawbook Co, 11 ed, 2009) 264-7; Department of Justice and Attorney General, 'Reform of Judicial Review in NSW' (Discussion paper, NSW Government, March 2011) 6-9.

152 See Roy Kennedy v Director-General of the Department of Environment and Conservation and Another [2006] NSWLEC 456, [85] (Jagot J); Country Energy v Williams; Williams v Director-General National Parks and Wildlife [2005] NSWCA 318, [74]-[75], [78]-[80] (Basten JA) ('Country Energy v Williams'); Anderson \& Anor v Director-General of the Department of Environment \& Conservation \& Ors [2006] NSWLEC 12, [143] ('Anderson v DECC No 1').

153 See, eg, Country Energy $v$ Williams [2005] NSWCA 318, [97]-[100].

${ }^{154}$ National Parks and Wildlife Act 1974 (NSW) s 87, later amended by National Parks and Wildlife (Amendment) Act 2010 (NSW) sch 1 item 33.

155 See, eg, Country Energy v Williams [2005] NSWCA 318; Anderson v DECC No 2 [2008] NSWCA 337.

${ }^{156}$ Anderson $v$ DECC No 1 [2006] NSWLEC 12.

157 Anderson $\vee$ DECC No 2 [2008] NSWCA 337

158 See Country Energy v Williams [2005] NSWCA 318, [74]; Anderson v DECC No 1 [2006] NSWLEC 12, [143].

159 Jonathan Auburn, 'Consultation' (Paper presented at Public Law and Judicial Review Seminar, London, 7 April 2008) 3; Kioa $v$ West (1985) 159 CLR 550, 584-585 (Mason J).

${ }^{160}$ NPWR reg $80 \mathrm{C}(9)$.

${ }^{161}$ See Ashton [2011] NSWLEC 1249, [115].

162 Allan Hawke, 'Report of the Independant Review of the Environment Protection and Biodiversity Conservation Act 1999' (Report, Australian Government, 30 October 2009) 263.
} 


\section{Law reform}

This section considers the third argument: that specific law reform measures may improve the problems of ineffective practices and unfulfilled purposes. The preceding evaluations indicate that the law may have a negative impact on consultation practices and purposes. If the law can have a negative impact on consultation practices and purposes, law reform may have a positive impact on the problems of ineffective practices and unfulfilled purposes.

NSW and the ACT are the only Australian jurisdictions without independent ACH legislation. ${ }^{163}$ The NSW Government is currently investigating independent ACH legislation with the aim of drafting ACH legislation by 2012. ${ }^{164}$ For the purpose of developing recommendations to form the basis of a submission to the NSW law reform, this section considers how ACH legislation in other Australian jurisdictions can inform NSW law reform; and what law reform measures may facilitate improvements to the problems currently facing consultation practices and purposes.

\section{ACH legislation in other Australian jurisdictions}

Although ACH management is a state responsibility, ${ }^{165}$ the federal government is responsible for issuing permits to harm ACH of national or world significance, ${ }^{166}$ and for making declarations to protect imminently threatened $\mathrm{ACH} .{ }^{167}$ However, the federal structure offers little to inform the NSW reform. There is no requirement that the Minister for Sustainability, Environment, Water, Population and Communities consult with Aboriginal people before permitting harm to $\mathrm{ACH}$ of national or world significance, ${ }^{168}$ or before making a declaration to protect imminently threatened $\mathrm{ACH} .{ }^{169}$ Consultation is either discretionary, ${ }^{170}$ or part of general public consultation. ${ }^{171}$ Federal legislation has been further criticised for its failure to support Aboriginal determinations of significance, oral submissions and confidential information. ${ }^{172}$

The Tasmanian structure offers little to inform the NSW reform. Although statute allows the Relics Advisory Council to advise the Minister for Heritage on permits to harm $\mathrm{ACH},{ }^{173}$ the Council has not operated since the 1980s. ${ }^{174}$ The learned consequence of no duty to consult is that consultation becomes a matter of institutional discretion. ${ }^{175}$

There is no legislative provision for consultation with Aboriginal people before permitting harm to $\mathrm{ACH}$ in Western Australia. ${ }^{176}$ Instead, the Minister for Aboriginal Affairs must consult with the Aboriginal Cultural Materials Committee. ${ }^{177}$ There is no requirement that the Minister appoint an Aboriginal member to the Committee. ${ }^{178}$ A 1995 review of the Western Australian legislation concluded the consultation structure fails to provide 'the [Minister] with sufficient material to ... make a fair and informed decision'. ${ }^{179}$ Such a structure is unlikely to inform the NSW reform.

${ }^{163}$ See NPWA pt 6; Heritage Act 2004 (ACT) pt 2, 5, 8.

${ }^{164}$ Working Party for the Reform of Aboriginal Heritage Legislation, above n 20, 2.

165 See generally Heritage Division, above n 22, 3.

${ }^{166}$ Environmental Protection and Biodiversity Conservation Act 1999 (Cth) ch 4.

167 See generally Aboriginal and Torres Strait Islander Heritage Protection Act 1984 (Cth); Heritage Division, above n 22, 3 .

168 See generally Environmental Protection and Biodiversity Conservation Act 1999 (Cth) ch 4.

169 See generally Aboriginal and Torres Strait Islander Heritage Protection Act 1984 (Cth) ss 9-13.

170 Ibid s 13(3).

${ }^{171}$ Environmental Protection and Biodiversity Conservation Act 1999 (Cth) pt 8.

172 See generally National Native Title Tribunal, above n 20, 12-18; see, eg, Aboriginal Areas Protection Authority, Submission to Department of Environment, Water, Heritage and the Arts, Discussion paper: Indigenous heritage law reform, December 2009, 5; Evatt, above n 101, 47-52, 113-114, 149; Indigenous Advisory Committee, Submission to Department of Environment, Water, Heritage and the Arts, Discussion Paper: Indigenous Heritage Law Reform, 2009, 14.

173 Aboriginal Relics Act 1975 (Tas) s 3.

${ }^{174}$ National Native Title Tribunal, above n 20, 54.

${ }^{175}$ See generally Aboriginal Heritage Tasmania, FAQs (2 August 2010) <http://www. Aboriginalheritage.tas.gov.au/faq.html>.

${ }^{176}$ Aboriginal Heritage Act 1972 (WA) ss 18, 39; see generally National Native Title Tribunal, above n $20,47$.

177 Ibid s 18(2).

178 lbid s 28.

${ }^{179}$ CM Senior, Review of the Aboriginal Heritage Act 1972 (Report, Western Australian Government, 30 June 1995) 90-91; see generally National Native Title Tribunal, above n 20, 47. 
As part of an integrated approach to development approvals and heritage protection, the ACT Planning Authority must send certain development proposals to the Heritage Council. ${ }^{180}$ The Council may advise the Authority of ways the developer may conserve heritage significance. ${ }^{181}$ There is no requirement to consult Aboriginal people before giving this advice, but one member of the Council must be Aboriginal. ${ }^{182}$ The Council must advise the Authority of any requirements under heritage guidelines. ${ }^{183}$ The Council may make heritage guidelines after giving a relevant Representative Aboriginal Organisation notice of the draft guidelines, and considering any comments. ${ }^{184}$ As previously mentioned, the notice and submission mode of consultation is inappropriate for Aboriginal people. Further, there are no statutory criteria guiding the Ministerial registration of an Aboriginal organisation. ${ }^{185}$ Interestingly, however, the legislation contains a list of 'heritage significance criteria'. ${ }^{186}$ This may assist an ACH significance assessment.

Before issuing a permit to harm $\mathrm{ACH}$, the Minister for Aboriginal Affairs and Reconciliation must take 'reasonable steps' to consult with the Aboriginal Heritage Committee, native title bodies, traditional owners, and any other Aboriginal party the Minister considers relevant. ${ }^{187}$ While Aboriginal information on significance is determinative, ${ }^{188}$ the Minister is under no obligation to consider consultation information in decision-making. Further, a failure to define 'reasonable steps' means what is reasonable is determined on a case-by-case basis. ${ }^{189}$ Widespread dissatisfaction with how Aboriginal information informs permit decisions partially explains the pending reform of ACH legislation in South Australia. ${ }^{190}$ The South Australian law reform discussion may help inform NSW law reform.

In 2003, Queensland replaced the permit to harm with the Cultural Heritage Management Plan ('CHMP'). ${ }^{191}$ If another development approval is required, a developer must prepare a CHMP. ${ }^{192}$ The developer must issue a notice of intent to prepare a CHMP according to the statutory consultation hierarchy. ${ }^{193}$ At the top of the hierarchy is the Aboriginal Cultural Heritage Body ('ACHB') for the area. ${ }^{194}$ The function of the ACHB is to identify the Aboriginal Party for the area. ${ }^{195}$ The legislation identifies an Aboriginal Party as the native titleholder, registered native title claimant, or someone who holds traditional or familial cultural authority. ${ }^{196}$ If there is no $\mathrm{ACHB}$, the developer must give notice of intent to prepare a CHMP to the Native Title Party for the area. ${ }^{197}$ The legislation identifies a Native Title Party as a native title holder, registered native title claimant, or failed native title claimant. ${ }^{198}$ If there is no ACHB or Native Title Party, the developer must put a notice in the local newspaper inviting any Aboriginal Party to participate in CHMP preparation. ${ }^{199}$

The ACHB concept excited Aboriginal interview participants because the Minister for Environment and Resource Management only registers an ACHB if satisfied the body has the support of the Native Title Party, or other Aboriginal Party, for the area. ${ }^{200}$ There are currently

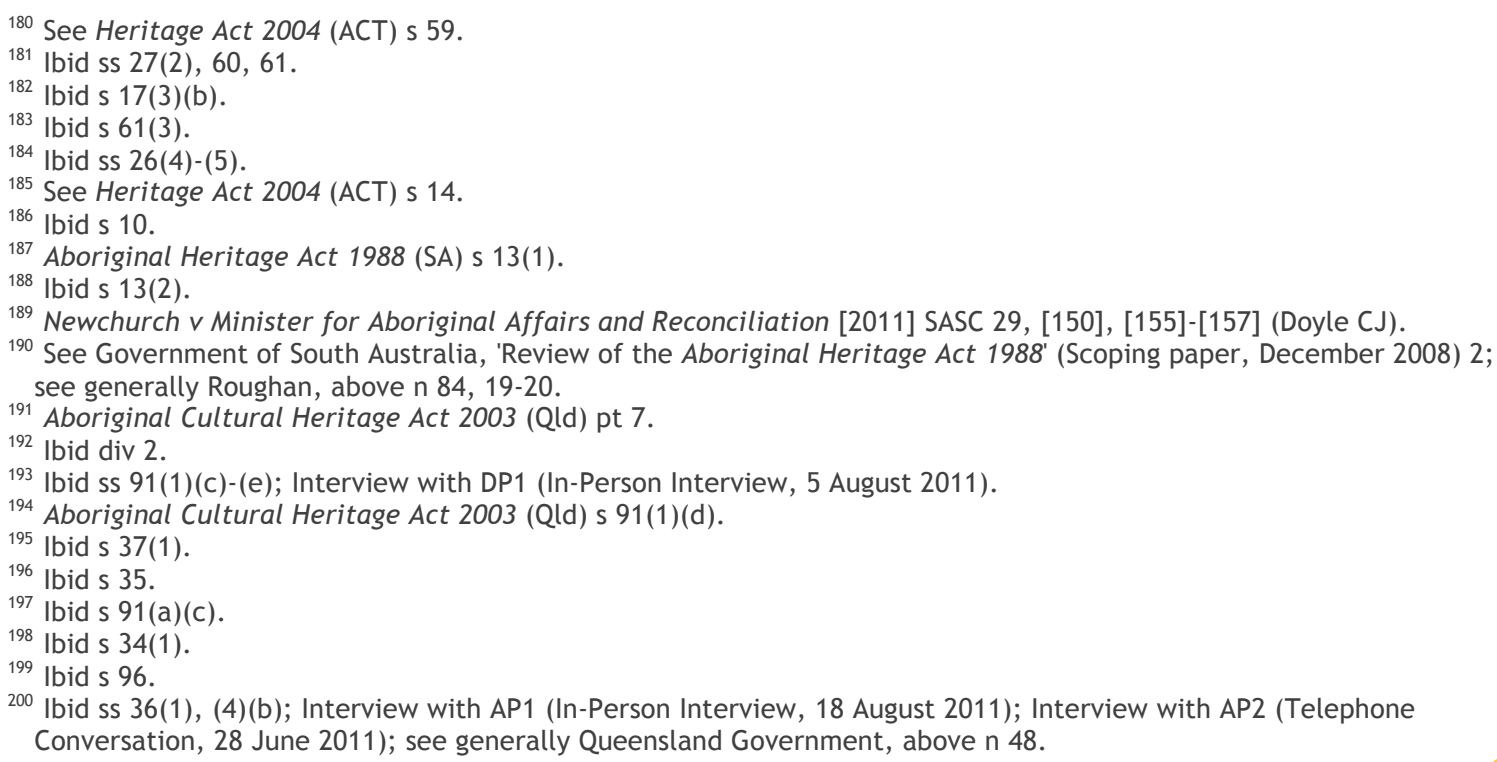


$37 \mathrm{ACHBs} .{ }^{201}$ Issues may arise, however, when there is no ACHB. In that case, the Native Title Party notice generally only extends to the individual named on the native title application, not to the claimant group, ${ }^{202}$ and 'a failed claimant has prime consultation rights if no one else lodges a subsequent claim'. ${ }^{203}$ When there is no Native Title Party, the requirement to consult with anyone claiming to be an Aboriginal Party may raise similar issues to those raised by the $N P W R$ open registration requirements.

In Queensland, the CHMP process occurs over a period of four months. ${ }^{204}$ Each party must consult and negotiate with each other for the purpose of reaching agreement on protection, conservation, avoidance and mitigation measures. ${ }^{205}$ If all parties agree, the Chief Executive of the Department of Environment and Resource Management must approve the CHMP. ${ }^{206}$ If an Aboriginal body refuses to approve the CHMP, the developer may seek mediation through the Land Court, ${ }^{207}$ or a recommendation from the Land Court that the Chief Executive approve the CHMP. ${ }^{208}$

The CHMP concept merits further research. It is possible that the Queensland CHMP model contains several concepts that may improve consultation practices and purposes. The legislation suggests information parties may wish to discuss in consultation, such as reasonable employment requirements, ${ }^{209}$ and suggests methods of communication, such as face-to-face meetings. ${ }^{210}$ These suggestions may help authoritative and relevant Aboriginal information inform the cultural assessment and decision-making. The legislation provides for the registration of cultural heritage studies prior to development issues arising. ${ }^{211}$ This allows for the early receipt of Aboriginal information, and may trigger the requirement to consult at the desktop planning stage. ${ }^{212}$

In Victoria, the Secretary of the Department of Community and Planning must refuse to grant a permit to harm ACH if a Registered Aboriginal Party ('RAP') objects to the issuing of the permit. ${ }^{213}$ This thesis does not investigate the merits of sharing executive decision-making power. As such, the effectiveness of the Victorian permit system is the domain of another paper. In any case, the Aboriginal Heritage Act 2006 (Vic) largely replaced the permit with the CHMP. ${ }^{214}$ If a development requires an approval under another law, the developer must have an approved CMHP before seeking development consent. ${ }^{215}$ Developers must give a relevant RAP notice of intent to prepare a CHMP. ${ }^{216}$ An RAP may respond with a notice of intent to evaluate the CHMP. ${ }^{217}$ If so, parties must then make 'reasonable efforts' to consult with each other, ${ }^{218}$ and to agree on harm avoidance and mitigation measures, $\mathrm{ACH}$ management issue, and dispute resolution mechanisms. ${ }^{219}$ An RAP may only refuse to approve a CHMP if the CHMP does not adequately address these matters. ${ }^{220}$ If a RAP refuses to give approval, the developer may seek a merits review in the state administrative tribunal. ${ }^{221}$ If there is no RAP for the area, the Secretary may approve the CHMP after consulting any Aboriginal person the Secretary considers relevant. 222

\footnotetext{
201 Queensland Government, Cultural heritage bodies (6 October 2011) <http://www.derm.qld.gov.au>

202 See Aboriginal Cultural Heritage Act 2003 (Qld) s 34(1).

203 Interview with DP1 (In-Person Interview, 5 August 2011).

${ }^{204}$ Queensland Government, above n 48.

205 Aboriginal Cultural Heritage Act 2003 (Qld) ss 102(1), 103(a)-(b).

206 lbid s 107(3).

207 Ibid ss 106(1)-(3)

208 Ibid ss 112(1), 113(1)-(2).

209 lbid s 104(1).

210 Ibid s 104(2).

211 lbid pt 6.

212 National Native Title Tribunal, above n 20, 31

213 Aboriginal Heritage Act 2006 (Vic) ss 38(2), 39(1)(c), 39(1)(b), (2)(b), 40(3), 41(1)(a).

214 lbid pt 4.

${ }^{215}$ Ibid pt 4 div 2, s 52(1); see also Holcim (Australia) Pty Ltd v Indigo SC [2011] VCAT 987, [5] (Deputy President Dwyer).

216 Ibid s 54(1)(a).

217 Ibid s 55(2).

218 Aboriginal Heritage Act 2006 (Vic) s 59(2)-(3).

219 Ibid ss 61, 62(4).

220 Ibid ss 63(1), 63(4).

221 Ibid s 116

222 Ibid ss 65(1)-(3)
} 
While the Victorian CHMP system appears similar to the Queensland CHMP system, the Victorian system contains several notable differences. The developer must be advised by an expert in 'anthropology, archaeology or history'. ${ }^{223}$ This may perpetuate the dominance of archaeological information. Further, and similarly to the South Australian structure, the Victorian legislation does not define what is meant by 'reasonable efforts' to consult. This means what is reasonable is determined on a case-by-case basis.

Of most concern in Victoria is the RAP registration system. The system appears meritorious as RAPs are appointed by a state body of Aboriginal people. ${ }^{224}$ Native titleholder applicants, and traditional owners who are party to a settlement agreement for the area, are registered as the RAP for the area to the exclusion of all others. ${ }^{225}$ However, issues arise in the absence of either applicant. In such a case, statutory registration criteria require the state body to consider incorporated applicants with traditional, historical, or contemporary links to the area. ${ }^{226}$ Arguably, these criteria aim to avoid an absence of Aboriginal representation in areas where there are no legally recognised traditional owners. ${ }^{227}$ The state body, however, have refused to register applicant groups unless they represent only, and all, traditional owners. ${ }^{228}$ This preference may explain why the state body has only approved nine RAPs in five years, ${ }^{229}$ why 'RAPs have approved [only] 338 plans out of a total of 1191 approved cultural heritage management plans', ${ }^{230}$ and why the RAP system is currently the subject of a Victorian parliamentary inquiry. ${ }^{231}$

A look at the Northern Territory consultation structure is a fitting end to the tour of Australian duties. There is separate legislation for objects and sacred sites. The Heritage Conservation Act 2008 (NT) requires the Minister for Natural Resources, Environment and Heritage to consider advice from the Aboriginal Areas Protection Authority before issuing a permit to destroy an Aboriginal object. ${ }^{232}$ The Authority must advise the Minister after consulting the traditional custodians of the object. ${ }^{233}$

The Sacred Sites Act 1989 (NT) created the Aboriginal Areas Protection Authority. ${ }^{234}$ All but two of the 12 members are custodians of sacred sites. ${ }^{235}$ The developer may submit an application to harm a sacred site to the Authority. ${ }^{236}$ The Authority has 60 days to consult with the traditional custodians of the site ${ }^{237}$ and take into account custodian wishes in deciding whether to approve the application. ${ }^{238}$ The developer may meet with custodians if the developer accepts the costs of the meeting, and custodians and the Authority consent to the meeting. ${ }^{239}$ The same process applies to approval variations. ${ }^{240}$

\footnotetext{
${ }^{223}$ Aboriginal Heritage Act 2006 (Vic) ss 58, 189(1).

224 lbid pt 9, 10.

225 Ibid ss 151(2)-(2A).

226 Ibid s 151(3).

227 Interview with GP1 (In-Person Interview, 8 August 2011).

${ }^{228}$ See, eg, Victorian Aboriginal Heritage Council, 'Decision of the Victorian Aboriginal Heritage Council in Relation to an Application by the Ballarat and District Aboriginal Co-operative Ltd to be a Registered Aboriginal Party' (3 December 2009); Victorian Aboriginal Heritage Council, 'Decision of the Victorian Aboriginal Heritage Council in Relation to an application by Framlingham Aboriginal Trust to be a Registered Aboriginal Party' (10 June 2010).

229 See generally Department of Planning and Community Development, Registered Aboriginal Parties (4 August 2011) $<$ http://www.dpcd.vic.gov.au>.

${ }^{230}$ See generally Department of Planning and Community Development, 'Review of the Aboriginal Heritage Act 2006' (Discussion paper, Victorian Government, September 2011) 14.

231 Committees, Inquiry into the Establishment and Effectiveness of Registered Aboriginal Parties (5 October 2011)

Parliament of Victoria <http: / /www.parliament.vic.gov.au/enrc/article/1419>.

${ }^{232}$ Heritage Conservation Act 1991 (NT) s 29(2).

233 lbid s 29(2).

${ }^{234}$ Northern Territory Aboriginal Sacred Sites Act 1989 (NT) pt 2.

235 Ibid ss 6(1)-(5).

236 Ibid S 19B.

237 lbid S 19F.

238 lbid ss 22(1)(b), (d), 42.

239 Ibid ss 19G, 19L.

240 lbid s 23.
} 
Some herald the Northern Territory structure as best practice, mainly because the structure separates $\mathrm{ACH}$ protection from development approvals. ${ }^{241}$ The structure is certainly unique in prescribing different consultation requirements for objects and place, and subjecting variations to the consultation process. However, it is worth noting that the structure allows the developer to make an application to harm $\mathrm{ACH}$ on a purely voluntary basis. ${ }^{242}$

\section{NSW law reform: the two-tiered model}

Some of the issues raised in the NPWR evaluations may be redressed by amending the current law. However, developers and Aboriginal interview participants feel that further amendments to a 1974 law may simply add new problems to existing ones. ${ }^{243}$ This is especially so as the main regulatory feature of the current duty to consult is connection between the developer, the CHAR and the consultation. The power given to the developer is concerning considering the inherent conflict of interest between development and $\mathrm{ACH}$ protection. The current law could be amended to vest consultation responsibility in the OEH. However, this merely moves the time and cost burden of consultation to government departments with limited resources while doing little to redress the power and capacity inequalities that Aboriginal people face in consultation. It is perhaps for this reason that the NSW Government also considers it time to start anew and has backed this belief with the Working Group for Reform of Aboriginal Cultural Heritage Legislation. ${ }^{244}$

The impending reform of $\mathrm{ACH}$ legislation in NSW provides an opportunity to extend the law reform discussion beyond amendments to the current duty. Several past ACH law reform inquiries have recommended a two-tiered statutory structure to redress some of the bigger issues facing ACH management. ${ }^{245}$ The two-tiered model comprises two different statutory bodies - an independent state $\mathrm{ACH}$ body and local $\mathrm{ACH}$ councils. ${ }^{246}$ As the NSW Working Group summarises:

The two-tiered structure ... was intended to allow for decision-making at a local or regional level, with a central body or commission to provide for the monitoring and review of locally made decisions, as well as for the resolution of disputes. ${ }^{247}$

The key features of the two-tiered model are the vesting of $\mathrm{ACH}$ ownership in Aboriginal people, the independent and state-wide Aboriginal management of $\mathrm{ACH}$, the provision of Aboriginal led dispute resolution processes and the devolution of $\mathrm{ACH}$ decision-making to local Aboriginal people. While issues relating to self-determination and sovereignty are relevant to any $\mathrm{ACH}$ reform discussion, they are beyond the scope of this article.

It is commonly agreed that the issue of who represents Aboriginal people at the state and local level must be resolved in consultation with Aboriginal people. ${ }^{248}$ However, some interview participant feedback is worth noting. Several participants supported transforming the current

${ }^{241}$ See, eg, Aboriginal Areas Protection Authority, above n 172, 2, 6; Senate Joint Committee on Native Title and the Aboriginal and Torres Strait Islander Land Fund, above n 52, [8.1].

242 Ibid s 19B.

${ }^{243}$ Interview with DP3 (Telephone Conversation, 23 June 2011); Interview with AP2 (Telephone Conversation, 28 June 2011); Interview with AP3 (Telephone Conversation, 25 July 2011).

${ }^{244}$ Working Party for the Reform of Aboriginal Heritage Legislation, above n 20, 2; see also Better Regulation Statement, above $\mathrm{n} 34,1$.

${ }^{245}$ See, eg, Select Committee of the Legislative Assembly upon Aborigines, 'Second Report' (Report, Parliament of New South Wales, 15 April 1981) 1; Aboriginal Cultural Heritage Working Group, above n 97, 30-32; State Aboriginal Heritage Committee, Aboriginal Congress of South Australia Inc, Local Government Association of South Australia, South Australian Chamber of Mines and Energy Inc, South Australian Farmers Federation, South Australian Native Title Services Ltd, Wildfish Fisheries SA Inc, Submission to South Australian Government, Review of the Aboriginal Heritage Act 1988, 30 October 2009, 12; see generally Working Party for the Reform of Aboriginal Heritage Legislation, above $\mathrm{n}$ 20, 5.

${ }^{246}$ See, eg, NSW Aboriginal Land Council, 'Our sites Our Rights - Returning Control of Aboriginal Sites to Aboriginal Communities: a Summary of Key Recommendations of Past Aboriginal Heritage Reviews in NSW' (Report, NSW Aboriginal Land Council, December 2010) 13-14.

${ }^{247}$ Working Party for the Reform of Aboriginal Heritage Legislation, above n 20, 5.

${ }^{248}$ See generally ibid; NSW Aboriginal Land Council, above n 246, 12-13 Interview with GP2 (Questionnaire, 21 August 2011). 
Aboriginal Cultural Heritage Advisory Committee into an independent state council. ${ }^{249}$ Alternatively, one Aboriginal interview participant suggested that state body membership could be 'made up from traditional owner groups who have successfully passed the Federal Court's native title registration test'. ${ }^{250}$ At the local level, further research is required on the appropriate geographical, political or cultural scale for each local ACH council. 251 Two Local Aboriginal Land Council interview participants suggested the local body might include equal representation from the following groups:

- native titleholders

- registered native tile claimants

- Aboriginal parties to Indigenous Land Use Agreements in the area

- Aboriginal representatives from the Local Aboriginal Land Council ${ }^{252}$

This recognises the traditional responsibilities of legally recognised traditional owners, and the statutory responsibility of the Local Aboriginal Land Council to protect ACH in the local area. ${ }^{253}$ However, another Aboriginal interview participant suggested membership based on documented genealogy:

Genealogy is the key to who should speak for country. All Aboriginal groups, organisations and Land Councils should provide this sort of information. There are traditional, displaced and historical Aboriginal people in NSW and each family or clan group in NSW knows where they originally come from - they just need to record and document this. ${ }^{254}$

A membership hierarchy based on documented genealogy may apply across NSW, including in areas where there are currently no legally recognised traditional owners.

The following discussion considers law reform measures within the two-tiered structure that may support an effective consultation process. An effective consultation process in regard to ACH is one designed to inform the cultural assessment and $\mathrm{ACH}$ decision-making. ${ }^{255}$ If the following discussion reveals that certain law reform measures may support such a process, there is support for the argument that law reform may improve the implementation of consultation practices and fulfilment of consultations purpose.

\section{That statute vests cultural rights to $\mathrm{ACH}$ in the local $\mathrm{ACH}$ council}

One interview participant expressed the personal view that the primary disadvantage of current AHIP consultations is 'the lack of bargaining power Aboriginal people have in the consultation process' ${ }^{256}$ The bargaining gap exists because the legal nature of Aboriginal rights in ACH is unresolved, ${ }^{257}$ while the legal nature of the developer's fee simple property right is clear and strong. ${ }^{258}$ The generally greater financial resources of the developer, ${ }^{259}$ and the vesting of consultation control in the developer, ${ }^{260}$ may exacerbate the bargaining gap.

A review of $\mathrm{ACH}$ legislation in other Australian jurisdictions suggests that law reform may reduce the bargaining gap and decrease Aboriginal disadvantage in the consultation process. Queensland and Victorian legislation attempts to reduce the bargaining gap by vesting ownership of secret and sacred Aboriginal objects with Aboriginal people. ${ }^{261}$ Northern Territory legislation appears to

\footnotetext{
249 Interview with AP1 (In-Person Interview, 18 August 2011); Interview with DP1 (In-Person Interview, 5 August 2011); Interview with AP2 (Telephone Conversation, 28 June 2011).

250 Interview with AP1 (In-Person Interview, 18 August 2011).

251 See generally Lane and Williams, above n 97, 48.

252 Interview with AP2 (Telephone Conversation, 28 June 2011); Interview with AP3 (Telephone Conversation, 25 July 2011); see also State Aboriginal Heritage Committee et al, above n 245, 12.

253 Aboriginal Land Rights Act 1983 (NSW) s 52(4)(a); see also NSW Aboriginal Land Council, above n $55,13$.

254 Interview with AP1 (In-Person Interview, 18 August 2011).

255 See State Aboriginal Heritage Committee et al, above n 245, 12.

256 Interview with GP2 (Questionnaire, 21 August 2011).

257 See generally Evatt, above n 101, 26.

258 Ibid.

259 See, eg, Sabine Elvy, 'Opinion: Is Consultation an Acceptable Standard in Conservation Laws?' (2009) 3 National Environmental Law Review 46, 48; Mahjabeen, Shrestha and Dee, above n 4, 58; Forward NRM, above n 4, 50.

${ }^{260}$ NPWR reg $80 C(1)$.

${ }^{261}$ Aboriginal Cultural Heritage Act 2003 (Qld) ss 19(1)-(2); Aboriginal Heritage Act 2006 (Vic) ss 21(1)-(2).
} 
decrease the gap by separating $\mathrm{ACH}$ protection issues from the development approval process. ${ }^{262}$ The indication in NSW is that independent $\mathrm{ACH}$ legislation will integrate protection and development issues. ${ }^{263}$ In this case, the bargaining gap may be somewhat reduced by vesting ownership of Aboriginal objects with Aboriginal people. However, a property right in objects does not reduce the bargaining gap in consultations concerning places or features of significance to Aboriginal people.

A statutory cultural right in $\mathrm{ACH}$ may reduce the bargaining gap in consultations concerning any $\mathrm{ACH}$. The notion of cultural rights permeates modern day international law. ${ }^{264}$ The United Nations Declaration on the Rights of Indigenous Peoples art 11.1 states:

Indigenous peoples have the right to practise and revitalise their cultural traditions and customs. This includes the right to maintain, protect and develop the past, present and future manifestations of their cultures, such as archaeological and historical sites, artefacts, designs, ceremonies, technologies and visual and performing arts and literature. ${ }^{265}$

Creating a cultural property right in $\mathrm{ACH}$ may help facilitate a consultation environment of equality. This increases the potential for Aboriginal information to inform the cultural assessment and $\mathrm{ACH}$ decision-making.

\section{That the state body develop significance assessment criteria}

One OEH interview participant noted that a significance threshold test might help resolve conflicts of information. ${ }^{266}$ It is possible for such a test to form part of a significance assessment standard developed by the state body ${ }^{267}$ A standard that outlined the assessment criteria for social, cultural, historical, aesthetic and archaeological values may help significance assessments met the international standards for heritage conservation adopted by Australia in The Burra Charter. ${ }^{268}$ Most importantly, a significance assessment standard may help resolve conflicts of information, ${ }^{269}$ ensure a balanced cultural heritage assessment, ${ }^{270}$ and inform $\mathrm{ACH}$ decisionmaking. ${ }^{271}$

\section{That each local ACH council complete a local cultural heritage survey}

$\mathrm{ACH}$ must be identified before its value can be assessed. ${ }^{272}$ Granted, not all Aboriginal objects, places and landscape features can be identified in advance. However, a local cultural heritage survey prepared by each local $\mathrm{ACH}$ council, in consultation with an archaeologist and in advance of development proposals arising, may help inform future cultural heritage assessments and $\mathrm{ACH}$ decision-making. A local survey may help inform future assessments and decision-making by providing a 'landscape perspective on history and culture', 273 'predict[ing] where presently unidentified places are likely to be found' ${ }^{274}$ and indicating areas where precaution may be required in development planning. ${ }^{275}$

${ }^{262}$ Aboriginal Areas Protection Authority, above n 172, 2.

${ }^{263}$ Office of Environment and Heritage, above n 24; see also Working Party for the Reform of Aboriginal Heritage Legislation, above n 20, 2.

264 International Covenant on Economic, Social and Cultural Rights, opened for signature 16 December 1966, 993 UNTS 3 (entered into force 3 January 1976) art 1; see generally Diana Ayton-Shenker, The Challenge of Human Rights and Cultural Diversity (March 1995) United Nations Department of Public Information <http://www.un.org/rights/dpi1627e.htm>

265 United Nations Declaration on the Rights of Indigenous Peoples, GA Res 61/295, UNGAOR, 61st sess, Supp No 49, UN Doc A/61/295 (13 September 2007) art 11.1.

266 Interview with GP1 (In-Person Interview, 8 August 2011).

267 See Heritage Conservation Act 1991 (NT) ss 18-20; Heritage Act 2004 (ACT) s 10; see generally Byrne, Bradshaw and Ireland, above n 97, 142.

${ }^{268}$ Burra Charter; see generally Byrne, Bradshaw and Ireland, above n 97, 142.

269 Interview with GP1 (In-Person Interview, 8 August 2011).

${ }^{270}$ See Byrne, Bradshaw and Ireland, above n 97, 141-142.

271 See generally Evatt, above n 101, 83; see Guilfoyle, above n 96, 6.

272 See ACH Consultation Requirements for Proponents, above n 21, 2, 8.

${ }^{273}$ Guilfoyle, above $\mathrm{n} 96,4$

274 Ibid 2; see generally Select Committee of the Legislative Assembly upon Aborigines, above $\mathrm{n} 245,318$

${ }^{275}$ See generally ACH Consultation Requirements for Proponents, above n 21, 2; Burra Charter art 3.1. 


\section{That the local survey be registered by an ACH Registrar}

Registration of each local survey by an $\mathrm{ACH}$ Registrar would ensure the survey met significance assessment standards. Further, an ACH Registrar could record local survey information using a flag system. A flag system allows ACH information to inform the cultural heritage assessment while respecting $\mathrm{ACH}$ cultural restrictions and integrity. Ultimately, registration of each survey may allow cultural heritage assessors and $\mathrm{ACH}$ decision-makers to consider properly the cumulative impacts to regional cultural values. ${ }^{276}$

\section{That the developer request a register search at the desktop planning stage}

Requiring a developer to request a register search at the desktop planning stage allows the $\mathrm{ACH}$ Registrar to give the developer the contact details for the relevant local ACH council. The developer is then aware of whom to consult at the desktop planning stage. Certainty of who to consult at the desktop planning stage may eliminate the duplication of consultation processes, and facilitate the early involvement of authoritative Aboriginal people in $\mathrm{ACH}$ identification, assessment, and protection. ${ }^{277}$

\section{That the developer submit development proposals and prescribed fee to the local ACH council}

Requiring developers to submit development proposals to the relevant local $\mathrm{ACH}$ council, with the fee currently paid by developers to archaeologists, ${ }^{278}$ allows the local ACH council to employ an archaeologist. The role of the archaeologist in this structure is to assist the local ACH council in drafting a CHMP for the development proposal. Empowering the local ACH council to employ an archaeologist may redress the balance between economic, archaeological and Aboriginal information. This increases the potential for authoritative and relevant Aboriginal information to inform the cultural assessment and $\mathrm{ACH}$ decision-making.

\section{That the local ACH council prepare a CHMP in consultation with the developer}

A local ACH council may need 60 days to conduct an on-site assessment, and draft a CHMP in consultation with the developer and archaeologist. To ensure a CHMP remains relevant for the life of the development, legislation should require a CHMP to accommodate:

- local survey information

- the results of any on-site assessment

- the 'measures to be taken before, during and after [the] activity to manage and protect $\mathrm{ACH}$ identified the assessment' 279

- compliance and enforcement responsibilities

Vesting responsibility for $\mathrm{CHMPs}$ with the local $\mathrm{ACH}$ council ensures that authoritative and relevant Aboriginal information informs the identification and assessment of $\mathrm{ACH}$, and the development of protection, conservation, avoidance and mitigation measures.

\section{That mediation be sought through the state body}

If the local ACH council and developer fail to reach agreement on the CHMP, the developer must seek mediation through the state body. This may reduce the call on limited government decision-making resources and ensure dispute resolution occurs in an environment that is appropriate and adapted to the consultation parties.

\section{That the CHMP be submitted to the $\mathrm{ACH}$ registrar for registration}

Submitting a mutually approved CHMP to the ACH Registrar allows the Registrar to ensure the CHMP is consistent with the local survey, and consistent with any legislative, regulatory or state

\footnotetext{
${ }^{276}$ See generally Aboriginal Cultural Heritage Working Group, above n 97, 36; Evatt, above n 101, 47-58; cf Senate Joint Committee on Native Title and the Aboriginal and Torres Strait Islander Land Fund, above $n$ 52, [7.2] - [7.22].

277 Interview with AP1 (In-Person Interview, 18 August 2011); Interview with DP1 (In-Person Interview, 5 August 2011); see generally Aboriginal Cultural Heritage Working Group, above n 97, 14; Indigenous Heritage Law Reform Discussion Paper, above n 52, 6; Urban Development Institute of Australia, above n 59, 8; Roughan, above n 84, $36,50,53$.

278 Interview with DP1 (In-Person Interview, 5 August 2011); Interview with AP1 (In-Person Interview, 18 August 2011); Aboriginal Cultural Heritage Working Group, above n 97, 12, 14.

279 Department of Planning and Community Development Victoria, Guide to Determining a Cultural Heritage Management Plan (2010) 1; see also Queensland Government, Cultural Heritage Management Plans (11 May 2011) <http://www.derm.qld.gov.au>
} 
body standards. Such a check also helps verify the authority and relevancy of CHMP information. These checks may take up to 14 days. After receiving notice of CHMP registration, the developer may apply for development consent.

\section{That the OEH approve if parties fail to agree}

Where the developer does not support certain CHMP conditions, and dispute resolution fails, the developer may ask the $\mathrm{OEH}$ to approve the CHMP for registration minus the disputed conditions. The decision-maker must seek advice on the proposed CHMP from the state body, ACH Registrar, and Minister for Planning, and seek submissions from the developer and local ACH council. This information, coupled with the information contained in the local survey and CHMP, constitute the criteria the decision-maker must consider. Such a process ensures the decision-maker has sufficient $\mathrm{ACH}$ and economic information on which to make an informed decision.

\section{That merits review be available to both parties}

If the OEH refuses to approve the CHMP minus the disputed conditions, the developer may seek merits review in the Land and Environment Court because the decision affects the developer's fee simple property right. ${ }^{280}$ If the OEH approves the CHMP minus the disputed conditions, the local ACH council may seek merits review in the Land and Environment Court because the decision affects the local council's previously mentioned cultural property right. ${ }^{281}$

\section{That statute requires the development of process evaluation criteria and annual evaluation}

It is important that an effectiveness evaluation of complex programs is designed from the beginning of the program and not left until the evaluation findings are required. ${ }^{282}$

Developing evaluation criteria at the outset of implementing the aforementioned law reform measures allows the local bodies to monitor the process and collect evaluation data on an ongoing basis. ${ }^{283}$ Collection of data on an ongoing basis will help inform an annual process evaluation. ${ }^{284}$ An annual evaluation will help inform future $\mathrm{ACH}$ reform.

\section{Preliminary conclusions on law reform}

Granted, the above process extends the current consultation timeframe from 56 days to 74 days. However, as one developer interview participant noted, the OEH may hold AHIP applications over pending more consultation. ${ }^{285}$ Further, heritage consultations may duplicate consultation undertaken as part of the planning process. ${ }^{286}$ As such, a 74-day timeframe may more closely reflect the time currently spent consulting Aboriginal people before permitting harm to $\mathrm{ACH}$. In addition, the proposed process has the potential to:

- provide certainty on who to consult

- reduce the call on limited government resources

- enable authoritative and relevant Aboriginal information to inform the cultural heritage assessment and $\mathrm{ACH}$ decision-making

This potential lends support to the argument that law reform may help improve the problems of ineffective practices and unfulfilled purposes.

\footnotetext{
${ }^{280}$ See generally Administrative Review Council, What Decisions Should be Subject to Merits Review (7 April 2011)

Australian Government, [2.4] <http://www.ag.gov.au/>

281 Ibid.

282 Office of Environment and Heritage, Design for Effectiveness Evaluation (2008) 1

<http://www.environment.nsw.gov.au/>

283 See ibid.

284 See generally Aboriginal Cultural Heritage Working Group, above n 97, 30-31, 146.

285 Interview with DP3 (Telephone Conversation, 23 June 2011).

${ }^{286}$ Interview with DP2 (Questionnaire, 12 October 2011).
} 


\section{Concluding remarks}

It is clear from the judgment in Ashton that consultation requirements may in effect defeat the purpose of the duty to consult. Researchers can help to minimise this perverse result by exploring the relationship between statutory consultation requirements and the purpose of the consultation. This article begins the conversation by examining the impact of the law on consultation practices and purposes.

Previous research assumes that key consultation issues relate to good or bad procedures and practices. Evidence related to the case study in this article suggests that the source of consultation issues may be the law. The case study consultation requirements were shown to lack the standards and specifications necessary to ensure the implementation of effective practices. The duty to consult was found to be ill-designed to fulfil the purpose of the consultation. These results suggest that statutory consultation requirements and purposes must be taken seriously for consultation to be more than a mere token gesture.

This article identifies specific requirements for Aboriginal consultations relating to cultural heritage, and how these requirements may be incorporated into $\mathrm{ACH}$ legislation. Consideration of these matters is particularly relevant in light of the fact that $\mathrm{ACH}$ protection and management is central to the international goals of Aboriginal rights recognition, sustainable development and NRM. More broadly, the law reform discussion indicates that when statutory consultation requirements are tailored to suit to purpose of the consultation and the consultation parties, the law can play a positive role in consultation, engagement and capacity building. 